\title{
The Salaries of Teachers in English Canada, 1900-1940: A Reappraisal ${ }^{*}$
}

\author{
R. D. Gidney and W. J.P. Millar
}

\section{ABSTRACT}

Any student of Canadian education during the first half of the twentieth century has encountered the belief, common among those engaged in the educational enterprise and sometimes shared by others, that teachers were badly paid for their work. Though not a universal assessment, a similar view has also dominated the historiography. This interpretation, we think, is overdue for revision. In this article we address two central questions. One focuses more narrowly on teachers' salaries per se: how much, on average, did teachers earn, and how did this change over time? The other asks, just how good or bad were their salaries compared to those of other people in the Canadian workforce? We tackle these questions on a Canada-wide basis, excluding only the province of Quebec, and over an extended period, covering the first four decades of the century.

\section{RÉSUMÉ}

Parmi les chercheurs et les étudiants intéressés par l'histoire de l'éducation canadienne pour la première moitié du vingtième siècle, un lieu commun persiste, à savoir, que les enseignants étaient très mal payés pour leur travail. Bien que cette assertion ne soit pas partagée par tous, ce point de vue domine dans l'historiographie de cette période. Nous croyons qu'il est temps de repenser cette interprétation. Dans cet article, nous nous intéressons à deux questions fondamentales. La première porte spécifiquement sur la rémunération des enseignants : combien gagnaient-ils en moyenne et comment leurs salaires ont-ils évolué dans le temps? La deuxième compare les salaires des enseignants à ceux versés aux autres travailleurs canadiens : étaient-ils pires ou meilleurs? Notre étude s'intéresse aux enseignants canadiens, à l'exception de ceux du Québec, et couvre les quatre premières décennies du vingtième siècle.

\footnotetext{
* This is a long essay and like any piece of work that uses large amounts of quantitative data, there is a need for technical explanations about the sources and the quality and interpretation of the data. In order to keep our references to a minimum we have chosen to confine much of this technical material to the appendix that accompanies the article. For the same reason we have relegated to the appendix some additional supporting commentary and documentation that, though germane, is not of central importance to our argument. It also includes our justifications for excluding Quebec (though occasionally some of the data do not allow its exclusion and we note these cases as we go along). To view the appendices, please visit the Historical Studies in Education website and click on the link "current": http://library.queensu.ca/ojs/index.php/edu_hse-rhe/issue/current
} 
Any student of Canadian education during the first half of the twentieth century has encountered the belief, common among those engaged in the enterprise and sometimes shared by others, that teachers were poorly paid for their work. Though more voluble at some times than others, there is a litany of complaints that teachers were under-paid and under-valued. Much of the historiography also reflects these views, frequently without either taking a close look at the data or subjecting contemporary commentary to critical scrutiny. Such assessments, however, have never been universal. There were always some observers who thought teachers were tolerably well paid, or at least took a more nuanced view of the question; and though almost always focused on particular provinces or limited time-frames, there are also historians who have drawn the same conclusion. ${ }^{1}$

These conflicting assessments deserve attention, and there is also a need to examine the problem beyond the bounds of particular regions or provinces, and across time. In this article, we propose to review the record on teachers' salaries in English Canada from the turn of the twentieth century to the late 1930s. We will address two central questions: The first focuses more narrowly on teachers' salaries per se; for instance, how much, on average, did teachers earn, and how did this change over time? The other asks, just how good or bad were their salaries compared to those of other people in the Canadian workforce? In the process of tackling these two questions, we hope to extend into the twentieth century some of the rich analysis already completed on the nineteenth, so as to offer an assessment of the relative economic status of Canadian teachers. We also hope to explore and then explain the earning differentials among teachers: those generated by different levels of education and experience, those between urban and rural teachers, and those between men and women. ${ }^{2}$

Though the same key questions recur, the essay covers two distinct time periods: we begin by focusing on the first three decades of the century; then we turn, more briefly, to the troubled years of the 1930s. The earlier decades, however, can hardly be described as "untroubled." They saw two periods of considerable prosperity: one extending to 1913, and the other to the middle and late 1920s. But they were also marked by a recession in 1913 that extended into 1915, by the disruptions in economic and social life caused by the Great War, by a brief post-war boom, and then by the post-war depression, short and sharp in some regions of the country, more prolonged and painful in others. Yet for public education this was an era of remarkable expansion, with unbroken and rapid growth in enrolments and near-continuous increase in expenditure. Enrolment growth fed the demand for more teachers and rising expenditure paid the salary bills. ${ }^{3}$ Between 1900 and 1930, the number of teachers in English Canada grew from about 19,000 to over 49,000, an increase of over $150 \%$. Total expenditure for teachers' salaries is available only for four provinces but it rose from $\$ 5,747,616$ in $1906-7$ to $\$ 50,067,344$ in 1930 , an increase of $771 \%$. These large increases, however, tell us nothing about what individual teachers actually earned or whether salaries went up or down: increasing total amounts, after all, might just mean more teachers paid the same or lower salaries. Thus the challenge is to gather the data that will allow us to make comparisons over time and between different places, and then to make sense of it. 
We exploit five main sources: the published census of Canada; the Annual Reports of the provincial departments of education; the annual surveys of education compiled by the Dominion Bureau of Statistics; various professional magazines directed at teachers; and an important study by the Canadian Teachers' Federation, Trends in the Economic Status of Teachers, 1910-1955. All of these have their limitations, but used judiciously and together, they provide a helpful overview of both national and provincial salaries across four decades. ${ }^{4}$ This material does not, of course, tell us about the experience of individuals: about conditions of classroom work, about lives lived in dramatically different communities or the special travails of those in isolated rural school districts, about disputes over contracts and tenure, about the everyday routines of negotiating with parents and trustees, nor even about teachers' satisfaction (or lack of it) with the salaries they earned. But we think it provides contexts and baselines for assessing the economic welfare of those engaged in teaching. ${ }^{5}$

\section{I}

We begin with average salaries, the national figures first, and then provincial differences. ${ }^{*}$ Though not entirely compatible, the census, CTF, and DBS figures all tell us that salaries rose at each data point during the first three decades of the century (Tables 1 and 2). Thus, on the face of it, salaries appear to be improving across the period. This, however, is quite misleading. Dollar amounts received or what we will term current dollars tell us nothing about what the dollars will purchase. What we really want to know is the comparative value of those dollars. The great advantage of the CTF study is that it converts current dollars into constant dollars that take account of the changes in the value of the dollar due to inflation or deflation. And in constant dollars, the pattern is different: between 1910 and 1920 average salaries in constant dollars dropped sharply, then rose substantially between 1920 and 1926, with more modest increases from 1926 to 1929 (Table 2).

The problem with the CTF's first two data points, however, is that they obscure important changes within the second decade of the century. Other sources tell us that prior to 1914 , salaries steadily increased, then stalled or sagged badly during the war years when they were frozen or cut and, at the same time, ravaged by inflation. Recovery began between 1918 and 1920, though in the latter year average salaries in constant dollars were still lower than in 1910 (and almost certainly lower than in 1913-14). All the evidence, on the other hand, confirms the CTF trend line for the 1920s: that is, rising salaries across the decade. ${ }^{6}$

This national pattern was replicated in each province: rising salaries to 1913 or 1914; reductions, freezes, or small increments running far behind the rate of inflation during the war; and increases during the 1920s. ${ }^{7}$ However, there were also striking differences between the various regions of the country (Table 3). According to the census of 1901, a persistent pattern was already established, with higher salaries in

\footnotetext{
* Throughout the text, the more familiar word "average" is used in place of but as a synonym for the more technical term "mean."
} 
the West and Ontario than in the Maritimes. Canada's best-paid teachers were in British Columbia: on average and in current dollars, they earned \$866 in 1910 and $\$ 1,466$ in 1929; for Nova Scotia the figures were \$291 and \$721 respectively (New Brunswick's figures were slightly higher than Nova Scotia's, Prince Edward Island's considerably worse). During the 1920 s teachers' salaries in Manitoba and Ontario improved substantially and in the Maritimes there were also considerable advances; in Alberta and especially Saskatchewan, the gains were much smaller. The result was that the gap between east and west narrowed somewhat, though somewhat is the operative word: in 1910, British Columbia's average salary figure was nearly three times as high as Nova Scotia's; by 1929 it was "only" twice as high.

But overall, were Canadian teachers better off in 1929 than in 1910? Certainly, their situation deteriorated between 1913 or 1914 and 1918 or 1919; nary a source challenges that conclusion. Setting those years aside, the answer is mixed. In constant dollars, earning power was higher in 1929 in Manitoba, Ontario, and the Maritimes due to considerable improvement between 1920 and 1926. In the three western provinces, however, salaries had been high in 1901 and 1910, and in 1929 teachers' earning power was no greater, indeed somewhat less, than it had been two decades earlier.

In the 1920s particularly, contemporaries were prone to suggest that salaries improved because teachers were better qualified and could, therefore, command better remuneration. There is no question that qualifications did improve. Before 1920 there had been very large numbers of teachers right across the country holding thirdclass certificates, or only temporary permits, requiring very modest levels of academic education and little or no professional training; by the end of the 1920s, these categories of teachers had very nearly disappeared. But after some fancy statistical footwork, the experts at the Dominion Bureau of Statistics concluded that improved qualifications between 1913 and 1929 could account for only 7\% of the difference. ${ }^{8}$ What mattered more was supply and demand. In the West, salaries were high before the Great War: rapidly increasing enrolments created huge teacher shortages, and teachers from the Maritimes and Ontario flocked west to take advantage of the higher salaries. During the war years, teachers all over Canada joined the military or opted for better-paying jobs in industry and commerce. As a result, a nation-wide shortage reaching crisis proportions developed and largely accounted for the salary spike of the early 1920s. But the post-war depression pushed up high school and normal school enrolments so that by mid-decade (and possibly as early as 1923) there were enough teachers to go around, and salary pressures eased for the rest of the decade. ${ }^{9}$

The figures marshalled thus far, however, beg a more important question: compared to others in the workforce, were teachers earning a lot or a little? In either current or constant dollars, after all, other people lost or gained across these three decades; just how well or poorly did teachers do by the typical wage or salary levels of the day? ${ }^{10}$ We will summarize the data at three points - prior to the Great War, for 1920-21, and for the late 1920s — and then offer an interpretation. One caveat, however: while some of the data in the section that follows are presented separately for men and 
women because totals are not available, we are not focusing here on gender differentials among teachers; rather our point is to contrast teachers' earnings with those for other occupations, men and women alike. We will return to the issue of gender differentials among teachers in the second part of the paper.

We begin with what we know about comparisons in the years before the Great War. Nation-wide, in 1901, women teachers earned, on average, \$246; this figure was higher than for women employed in manufacturing (\$193) or trade and transportation (\$238), and well above the average for domestic service (\$137) or for all women's occupations (\$182); their earnings were only slightly below those of all "professional" women (a category that also included government and municipal employees, and "stenographers and typewriters," who earned an average of $\$ 259 .{ }^{11}$ Drawing on a sophisticated analysis of the 1901 household census, Eric Sager provides a helpful baseline for the province of Ontario, where teachers ranked among the better-paid employed women, with salaries equal to those in the more general professional category. Sager concludes that "compared to other occupations for women, teaching was relatively rewarding....women teachers...had the material status of other women workers in respectable white-collar occupations: government clerks, librarians, stenographers, bookkeepers, and telephone operators." 12

Nationally, in 1901, male schoolteachers earned an average of \$486, more than the average for male wage-earners overall (\$387) but less than the average in "mining" (\$514) or "trade and transportation" (\$503), which included bookkeepers, office clerks, and salesmen. There was, however, a considerable gap between the average salary of male teachers and that of all men in the professional category (\$677). Among the latter, clergy, government employees, and engineers all earned more than teachers. ${ }^{13}$ We do not have the figures for doctors, dentists, or lawyers, but no doubt their earnings would have placed male teachers even more firmly towards the bottom of the list. Thus, we conclude that in 1901, the salaries of male schoolteachers compared less favourably with those of other men, particularly those in white-collar and professional occupations, than did the salaries of women teachers compared to other women. Indeed, adds Sager, "women teachers compared well with the earnings of many men: 27 per cent of male employees were earning less than the national average for women teachers." 14

CTF figures for 1910 compare all teachers' earnings to the average "personal income per person in employed labour force" (INLF) in Canada. ${ }^{15}$ In that year, Canada-wide, teachers made 69\% of INLF, but there were vast differences among provinces. In British Columbia the figure was $134 \%$, in Ontario, $81 \%$, in Nova Scotia, 45\%. Only in Ontario are these percentages given by gender for elementary teachers alone: male elementary school teachers earned $102 \%$ of INLF, and female, $70 \% .^{16}$ In another study, David Stager compares elementary teachers' salaries, for Ontario only, to the "general wage index" (the "average wage rate for selected main industries in Canada”). In 1901, both male and female teachers fell somewhat below it; by 1913, women were slightly above it, and men somewhat more so. ${ }^{17}$ In his 1913 book on Rural Schools in Canada, James C. Miller compared teachers' salaries province by province to the average daily wage of a selected group of skilled and 
unskilled wage-earners. "The teacher, on average, and especially in the case of rural school teachers, finds a place in the wage scale just above that of unskilled labor and below that of the skilled trades," he concluded. Teachers in the western provinces earned "higher salaries relatively as well as absolutely when the wages in other occupations are considered;" however, within the West itself, "the rural teacher and the rank and file of teachers in the towns and cities have not as yet, from an economic point of view, attained the rank of a skilled laborer." ${ }^{18}$ Trying to sum up this handful of findings for the period 1901 to c. 1914 is a precarious enterprise but it might go something like this: in the pre-war years, women teachers were comparatively well paid as against other female occupations, and, on average, men teachers were keeping pace with wages in other occupations; but most teachers made no more than skilled workers, and in some provinces, even less.

For the years around 1920 there are several useful comparisons. First, there are the CTF data for 1920. Measured, again, in terms of the average income per person in the employed labour force across Canada, teachers' salaries compared to those of others had clearly declined since 1910. Although in current dollars the average salary of teachers nation-wide was $\$ 841$, almost double the 1910 figure, in constant dollars it was actually less than in 1910, and the figure for INLF had dropped from 69\% to 64\%. There were provincial variations, but almost everywhere, teachers experienced the same loss of relative standing. Though the western provinces fared better, and the eastern worse, only male elementary school teachers in Ontario made more, very slightly (102\%), than the average INLF; female elementary school teachers in Ontario, much less (62\%). ${ }^{19}$ Wage-earners in the manufacturing industries earned a higher percent of INLF $-83 \%$ of the average income - than teachers, and the average of salaried employees in manufacturing was more than twice that of teachers, at $137 \%$.

A second measure, the 1921 census, provides comparisons of teachers' average earnings per week with those of various selected occupations, both Canada-wide and for the provinces. ${ }^{20}$ Again, the figures are given only for males and females separately. Male teachers in Canada (including Quebec) earned an average weekly wage of $\$ 27.70$; that put them eleventh among 34 selected occupations, below for example professional engineers $(\$ 39.83)$, steam railway conductors $(\$ 41.54)$, and telegraph operators $(\$ 30.89)$, but above carpenters $(\$ 24.24)$, policemen $(\$ 26.06)$, and salesmen $(\$ 22.33)$. Female teachers earned much less per week than male teachers, at $\$ 16.41$, but were relatively well paid compared to other female occupations: of fifteen selected occupations, teachers earned less than only one other (telegraph operators, who made $\$ 18.46$ a week). Rankings of occupations within each province varied, however, and teachers' relative standings shifted accordingly. For example, male schoolteachers in Ontario and British Columbia, compared to other occupations, were better off than the national average, ranking fifth and sixth within their provinces (earning \$33.07 and \$34.19 respectively); those in Nova Scotia, where, as in other maritime provinces, wages were generally lower, earned much less compared to other occupations, standing seventeenth (at \$23.02). In Ontario, Alberta, and British 
Columbia, female schoolteachers earned the highest weekly wages of all fifteen female occupations, while in Nova Scotia, they earned less than telegraph operators, hairdressers, and weavers. ${ }^{21}$

Two more circumscribed studies are also worth noting. A report by a Manitoba commission in 1919 provides for that province a careful estimate of average earnings of various occupations compared to teachers' salaries. It found teachers "outside of cities" to average $\$ 791$ a year; this put them below skilled trades $(\$ 1,500)$, nurses $(\$ 1,000)$, shop clerks $(\$ 1,200$ for men, $\$ 900$ for women), and experienced telephone operators ( $\$ 810$ in the country, $\$ 870$ in cities), and above domestic servants $(\$ 700)$ and inexperienced rural telephone operators $(\$ 640)$. The commissioners thought the comparison between teachers and nurses was particularly apt "as the period of training and expense thereof approximates to that of a second class teacher." 22 The other study, by the DBS, provides from the 1921 census a comparison of teachers' earnings with those of employees in "public administration" in fifteen cities across Canada. This too is useful because it compares two similar urban occupations: they were white-collar, middle- and lower-middle-class jobs that required educational credentials. Men made more than women in either teaching or public administration. Presumably, as well, men held a wider range of jobs and most of the senior jobs in both occupations. But both men and women teachers were paid more than their counterparts in public administration. For women the study had this to say:

In the 15 cities the numbers of females in teaching and in public administration are roughly the same so that it is an even chance whether a girl will enter upon the career of teaching or public administration in these cities, either because the two are equally attractive or that approximately the same number of positions is open in both callings. The average earnings in the teaching profession, however, are considerably higher. ${ }^{23}$

Collectively, these data may appear ambiguous; the problem is that they measure different things. However, they do at least indicate the following. First, by 1920, and in the aggregate, teachers' salaries had suffered a relative decline over the previous decade. Second, for both men and women teachers the occupation had largely maintained the same relative economic standing; but since the vast majority of teachers were women, most teachers were no better off than skilled workers, and in some cases below that. It is also clear that there remained vast differences between provinces in occupational ranking; in the east, teachers were paid much less than in the west. Similarly, there was a large divide between the salaries of rural and urban teachers, illustrated by the contrasting evidence from Manitoba and the public administration study.

Finally, what of the last half of the 1920s? According to the CTF figures, in 1926, teachers made $89 \%$ of the average income of all employed persons in Canada, and $88 \%$ in 1929 . That was a clear gain over their position in 1910 or 1920 . The figures varied considerably by province, however. In British Columbia, they were relatively 
better off than the Canadian average, at $124 \%$ of INLF in 1926 and $121 \%$ in 1929; in Alberta, Saskatchewan, and Manitoba, teachers made somewhere around the same as the average income, and in the maritime provinces, while they had improved their relative standing, in 1929 teachers in Nova Scotia still made only 60\% of the national INLF, in New Brunswick, 67\%, in Prince Edward Island, 46\%. In Ontario, the only province in which we can distinguish teachers by gender, male elementary school teachers made $141 \%$ of INLF, while female elementary school teachers' earnings were exactly equal to the average national income.

Although it begins only with the 1926 data, another measure used in the CTF study takes into account the differences in provincial economies: that is, it gives, for each province, teachers' salaries as a percentage of the average income per capita in that province. Since the same measure is given for both wage-earners and salaried employees in manufacturing industries in each province, the salaries of all three groups can be compared at a provincial rather than national level. In both 1926 and 1929, in most provinces, teachers made more than the average wage but less than the average salary in manufacturing industries; in general they were closer to the wage-earner than the salariat (see Table 4). ${ }^{24}$

To supplement the CTF data for the late 1920s, we can also turn to the 1931 census. ${ }^{25}$ Male school teachers made an average of $\$ 31.22$ per week employed, and female teachers, \$18.32; that meant that men's salaries ranked seventeenth out of 65 selected male occupations, and women's, third out of 30 female occupations. Roughly the same hierarchy prevailed: male accountants, professional engineers, retail managers, and telegraph operators all had higher earnings per week than male teachers, while policemen, salesmen, and carpenters had lower. For women, "graduate nurses" (i.e. those trained in a hospital) now joined telegraph operators in earning more per week than teachers. Provincial standings were also much the same as in 1921. Male teachers in Ontario and British Columbia were relatively well paid compared to other male occupations, standing ninth out of 65. In Nova Scotia they earned less than almost half of other occupations. Alberta's male teachers were almost as low in rank (23rd out of 61), which was much the same as in 1921. Female teachers in Ontario, Alberta, and British Columbia continued to earn salaries, on average, that were higher than all but those earned by female telegraph operators. Nova Scotia women teachers, on the other hand, fell to sixth place out of 29 female occupations; in a province of generally low wages, they averaged less than graduate nurses, bookkeepers, and stenographers, among others.

To summarize: using the only three consistent measures we have at our disposal for comparisons for the twenty years between 1910 and 1929, the changes over time look something like this. In constant dollars, national average salaries of teachers rose from $\$ 446$ to $\$ 622$, an increase of $40 \%$. In 1910 teachers stood at $69 \%$ of INLF; by 1929 , at $88 \%$ of INLF, or $12 \%$ below the average income of employed persons in Canada. The third measure, added in 1926, tells us that, within each province, teachers' earnings fell somewhere between the averages for wage-earners and salaried workers in manufacturing industries, though more towards the former than the latter. In Ontario, the CTF salary figures reveal a sharp improvement for male elementary 
teachers between 1910 and 1929 (from 102\% of INLF to 141\%), and a more modest improvement for female elementary teachers (70\% of INLF in 1910 to $100 \%$ in 1929). ${ }^{26}$ David Stager's figures for Ontario from 1902 to 1928 show a similar pattern: measured against the general wage index, considerable improvements for both men and women but more modest for women than men. ${ }^{27}$ Clearly, then, by the late $1920 \mathrm{~s}$ Canadian teachers had improved their lot since 1910, and, if we can use the early census figures, since 1901. But that brings us to the crux of the matter: the fact is that even in the last half of the 1920 s they were making, on average, some $10 \%$ or $12 \%$ less than the average income of all employed persons. Moreover, at some points in time and especially in some provinces, the evidence indicates that teachers were paid no more than skilled wage-earners, and in some instances less.

That conclusion, however, raises the key question at stake here. Should we treat it as good or bad news? Do we take it as proof that teachers were, comparatively speaking, poorly rewarded for their work, or can the cumulative evidence be read in a different way? To interpret the comparison we think it essential to take account of the differences in the structure of the two workforces: the general workforce, on the one hand, and teachers, on the other. Put simply, we have to be sure we are not comparing apples and oranges. The average income per person employed in Canada (or, as of 1926 to 1929 , the average wage or salary in manufacturing in each province) reflects the earnings of a predominantly male workforce. ${ }^{28}$ And that average incorporates a full age range from the youngest and most inexperienced employees to mature adults at their peak earning power. The bulk of the workforce in elementary school teaching, on the other hand, consisted of women - between 1910 and 1930, in English Canada, about 80\%. And high turnover rates in teaching made for a very young workforce, women and men alike: in 1921, for example, nearly $30 \%$ of males and $50 \%$ of females were under 25 ; almost $60 \%$ of males and $80 \%$ of females were under 35 , substantially larger proportions than for the same age range in the general workforce. $^{29}$

Youth was accompanied, naturally, by relative inexperience. We do not have comprehensive records on experience until well into the century, but there is no lack of commentary. For the first decade of the century, using age as a surrogate for the years a teacher had worked, James Miller thought it a safe generalization "that the great majority of rural teachers in Canada are between 17 and 23 years of age. Youthfulness, with inadequate experience in life, learning, and professional work is one of the chief characteristics of rural teachers." ${ }^{30}$ In 1915, Harold Foght prepared a careful statistical profile of rural teachers in Saskatchewan. Of 2,301 teachers reporting, 1,400 were 25 years old or less and 684 were between 17 and 20 . Thirty percent had only one year of teaching, $14 \%$ had one to two years, $23.2 \%$ had two to five years, and $24.6 \%$ had five years or more. ${ }^{31}$ Between 1910 and 1920, nearly $70 \%$ of Nova Scotia's teachers had five years experience or less and just over $40 \%$ had two years or less. ${ }^{32}$ Ontario collected annual data on total experience across several decades: in 1910, urban elementary teachers averaged about eleven and a half years and rural teachers five years 
of experience; these figures hardly budged through to $1920 .{ }^{33}$ Though the average amount of experience tended to increase through the third decade of the century, the gains were modest and lack of experience among rural teachers in particular remained common. By 1931 the Dominion Bureau of Statistics was able to pull together, for four provinces containing a majority of English-Canadian teachers, statistics on experience documenting the continuing trend. Some $62 \%$ of all Nova Scotia's teachers had been on the job for less than five years; among rural and village teachers, that figure rose to $77 \%$. In New Brunswick, $59 \%$ of teachers in ungraded schools had less than five years experience (versus 29\% in city schools); in Ontario, 57\% of teachers in rural schools; in Manitoba, $62 \%$ of teachers in rural ungraded schools. ${ }^{34}$ In the same year, in British Columbia's rural and assisted elementary schools, 55\% of teachers had less than five years experience. ${ }^{35}$

Given this profile for gender, age, and experience, it would be surprising if teachers' average salaries were higher than those of the predominantly male general workforce. Indeed, only $10 \%$ or $12 \%$ less than the average earnings of all persons employed in Canada strikes us as a fairly impressive figure. Moreover, while teachers' salaries, in 1926 or 1929, were below the average earnings for salaried workers in manufacturing industries, even this comparison needs interpretation since the salaried group included a larger proportion of well-paid managers, supervisors, and other senior clerical workers than it would two or three decades later. ${ }^{36}$

Another way of sizing up the situation is to compare teachers' wages in 1929 with Leonard Marsh's analysis of the census figures for 1931. In 1929, the average earnings of Canadian teachers were, in current dollars, \$1,061 (Table 2). This put them at the lower end of the top $40 \%$ of all male Canadian employees, in the same range ( $\$ 950$ to $\$ 1,450$ ) as the best-paid skilled workers and lower-paid clerical workers. ${ }^{37}$ "Half of the breadwinners [adult male heads of families]," wrote Marsh, "get between $\$ 500$ and $\$ 1,500$ a year... [and] it is safe to say that two-thirds of all married men of employee status, between one year and another, do not earn more than $\$ 1,200$. But more than $40 \%$ of this group earn less than $\$ 500$, or less than 10 dollars a week." 38 Again, one has to pit these figures against a workforce in teaching that was predominantly female, young, and new at their jobs.

One reasonably unambiguous conclusion from our survey is that women teachers, across the entire period from 1901 through 1931, were, on average, well paid compared to other female-dominated occupations. There were individual exceptions - women doctors, university-educated public health nurses, women with specialized skills or outstanding talent in commercial jobs. ${ }^{39}$ But as an occupational group, women in teaching were at or near the top. Aside from the data already cited on this point, there is Marsh's conclusion for 1931: "The count of incomes of all female wage and salary earners...shows more than three-quarters to be lower than $\$ 1,000$, and 90 per cent less than $\$ 1,500$. The modal group, because women workers are primarily a youthful component of the national labour force, is under $\$ 500$." ${ }^{40}$ Teachers, moreover, were never on short time, rarely laid off during the middle of the work year, ${ }^{41}$ and increasingly in the 1920s had provincially sponsored pension plans. ${ }^{42}$ In Marsh's index of the "security-income" rating of occupational classes measuring the average earnings 
per week, employed women teachers ranked relatively high. ${ }^{43}$ Aside from federal, provincial, or municipal civil servants, and a handful of highly organized craft unions, few Canadian workers, either blue or white collar, could claim the same sort of job security and benefits as teachers.

\section{II}

Average salaries, which lump all teachers together, go some distance towards illuminating the relative standing of teachers compared to the general workforce. But for a more sophisticated assessment it is essential to disaggregate the averages in order to take account of the salary differentials that existed across the period. These include rural/urban differentials, those generated by different educational levels, those between one-room and multi-grade schools, and those which were gender-based.

There were two distinct markets for teachers, for men and women alike. Wherever and whenever they had a choice, urban school boards gave preference, not just to the better qualified, but to the experienced teacher. Boards in the larger towns and cities near-uniformly required that applicants have at least two or three years of successful teaching experience. ${ }^{44}$ The urban job market, moreover, was highly competitive not only because of the amenities of town life or the higher salaries on offer but because most urban boards had established salary schedules based on a grid that took account of qualifications, experience, grade taught, and the like. ${ }^{45}$ This meant, in turn, that teachers could count on progressive salary increases as a reward for their work. Urban schools were thus a magnet for well-qualified and experienced teachers.

Even within the urban market for teachers there were substantial salary differences. The scarcity value of an undergraduate degree or a superior first-class certificate meant that, with few exceptions, high school teachers made more than elementary school teachers. ${ }^{46}$ In Ontario in 1906-7, for instance, high school teachers made on average very nearly twice as much as male elementary school teachers $(\$ 1,039$ versus \$547) and though the percentage differential narrowed somewhat over the years, the difference in dollar amounts actually increased by 1929-30 (\$2,472 versus $\$ 1,720) .{ }^{47}$ In the mid-1920s in New Brunswick, high school teachers earned, on average, $\$ 2,167$, about $\$ 900$ more than a male elementary school teacher with a firstclass certificate. ${ }^{48}$ In Toronto in 1929, high school teachers (male and female alike) began at $\$ 2,000$, with a maximum of $\$ 3,400 .{ }^{49}$ Both minimums and maximums for women were somewhat lower in Vancouver and Winnipeg but even then the maximums were $\$ 2,900$ and $\$ 2,800$ respectively. We have no minimum for Saint John but the maximum for women was $\$ 2,400$. Male high school teachers in Vancouver could reach a maximum of $\$ 3,200$, in Winnipeg, $\$ 3,400$. In Saint John, the figure was $\$ 2,500$. This put high school teachers, women as well as men, in a very exclusive salary group, making the same kind of money as only $8.4 \%$ of all male employees and $13.4 \%$ of adult male family heads. ${ }^{50}$

Elementary school teachers, male or female, in Canada's big cities could anticipate incomes almost as substantial. Toronto's male elementary school teachers in 1929 started at $\$ 1,625$ and could earn a maximum of $\$ 3,000$; for females, it was $\$ 1,000$ 
rising to $\$ 2,400$. The average salary of a male elementary school teacher in a city school in Ontario, with 6 to 10 years of experience and a first-class certificate, was $\$ 2,249$; of a woman with equivalent qualifications, $\$ 1,406 .{ }^{51}$ The maximum salaries in Vancouver and Winnipeg for men were $\$ 2,700$ and $\$ 2,800$ respectively; for women, $\$ 2,400$ and $\$ 2,200$. Even on the east coast, in Saint John, male elementary school teachers could reach a maximum salary of $\$ 1,975$, and women, $\$ 1,425$. In Leonard Marsh's judgement, most of these earnings were securely middle-class, and even beginning salaries were closely approaching that bracket. ${ }^{52}$ These were, of course, salaries in some of Canada's largest cities. They would be lower as one moved down the urban hierarchy and would also vary by region, but so would living costs and the incomes of employees in other occupations. ${ }^{53}$

Rural Canada constituted a different kind of market. Though by the 1920 s several provinces had enacted minimum wage laws for teachers, these were generally set low enough to encompass the extant salaries in the majority of rural school districts, and even then exceptions could be made for the poorest districts. ${ }^{54}$ Salary schedules were almost unknown; wages were set at the minimum that rural school trustees believed they could afford to pay and still attract a candidate of at least modest competence. Thus, in the main, the nation's one-room schools were the preserve of the least wellqualified, and above all, the beginner, regardless of qualifications. As one Manitoban put it in 1923, "At present the country is at once the training ground of the efficient teacher and the execution yard of the inefficient....Having stood the test, the young teacher passes on to town or city or it may be to another profession and a younger and less experienced one takes the vacant place." 55

Not surprisingly, rural salaries were substantially below those in urban Canada. In 1905 in the new province of Alberta, for example, male and female teachers with second-class certificates earned, on average, \$685 and \$591 respectively in the towns; in rural schools, the comparable figures were $\$ 603$ and $\$ 562 .{ }^{56}$ In Saskatchewan in 1914, an urban woman elementary teacher, who was most likely to hold at least a second-class certificate, earned, on average, $\$ 820$; her rural counterpart, most likely with a third-class certificate, $\$ 757 .{ }^{57}$ In the mid-1920s, the median salary for elementary school teachers in British Columbia's cities was \$1,372, and \$1,103 for those in "rural and assisted" schools. ${ }^{58}$ In Nova Scotia in the late 1920 s the difference was $\$ 1,066$ for urban teachers and $\$ 545$ for rural teachers. ${ }^{59}$ Whether one considers male or female salaries in Ontario, from the turn of the century through 1929 there was always a considerable differential in salaries between urban and rural men, or urban and rural women. ${ }^{60}$ In interpreting the meaning of average salaries, especially in the first half of the twentieth century, these differences are important because rural teachers constituted a substantial portion of the entire corps of Canadian teachers, and the earlier the decade, the larger that proportion was. ${ }^{61}$ Unless all the necessary qualifications are made, combining the effects of two distinct markets to arrive at an average salary obscures as much as it illuminates.

But just how well were these rural teachers paid compared to other members of the community? What, indeed, constitutes an apt comparison? Like earnings for other categories of the self-employed, total farm incomes were not captured in the 
census, and the best available figures we have are estimates or samples. Moreover, the estimates are Canada-wide and do not reflect differences in farm income by region. According to the CTF study, in 1928 the average self-employed farmer's earned income was $\$ 947$; in the next year it dropped to $\$ 599 .{ }^{62}$ Another study estimated that the figure for "cash income per farm" in 1931 was $\$ 648 .{ }^{63}$ There are other estimates that attempt to incorporate the value of goods produced and consumed on the farm itself and these assign somewhat higher incomes for farm families. ${ }^{64}$ But we suggest that earned income is a peculiarly useful reference point by which to judge the salaries of rural teachers for the simple reason that property taxes for the support of education (including, obviously, teachers' salaries) had, like other municipal taxes, to be paid in cash B that is, exclusively out of "earned income." In 1928-29, teachers in rural Nova Scotia earned, on average, $\$ 545$, and women teachers in rural Ontario, $\$ 997 .{ }^{65} \mathrm{In}$ Alberta, nearly all rural teachers were earning at least the minimum salary set by law, $\$ 840$; most New Brunswick rural teachers at least the minimum of between $\$ 500$ and $\$ 700 .^{66} \mathrm{~J}$.D. Wilson, commenting on rural teachers' salaries in British Columbia in 1931, remarks that

the average weekly wage in Canada in 1931 was $\$ 22.56$ for men and $\$ 12.01$ for women. At about the same time the average salary for a teacher at a rural assisted school was $\$ 1,080$ per annum or $\$ 20.76$ per week. So in terms of disposable income, rural female teachers, especially if single, were not badly off compared to women in other female occupations such as domestic servant, stenographer and typist. ${ }^{67}$

Given the fact that most of these rural teachers were young, single, and female, many of them only beginners, many of them boarding for only four or five days a week and returning home for weekends and holidays (or living at home), it is at least plausible to suggest that even rural teachers were relatively well paid for their services - if not in the hard years of the war, at least in the 1920s. ${ }^{68}$ And, perhaps it is fair to add, "not badly off "compared to what a farm family might expect in income for their combined labours.

Even if we are right that teachers, compared to others in the workforce, were tolerably well paid, it is obvious that women teachers were generally paid less than men. This is hardly an original observation on our part, but given the influence of the dual market for teachers' services, we also want to suggest that the differential was not universal. On the face of it, even this seems counter-intuitive. When one isolates provincial or national figures for rural schools, there appear to be persistent differences in the average salaries for men and women: though usually relatively modest, they existed nonetheless. ${ }^{69}$ But the rural figures tend to include two- or three-room schools, some in purely rural school districts, though most in hamlets and small, unincorporated villages, where one teacher, usually an experienced male, was designated principal. That is, these data do not allow us to segregate salaries by rank, qualifications, and experience, so that even in rural areas, gender differentials appear embedded. But what happens when we isolate the one-room school, the true 
realm of the beginner and least qualified?

There is, in fact, an Ontario source that allows us to probe that question: for much of the period, the province published detailed records for individual teachers, male and female, school by school, including among other things their salaries and qualifications. These are organized by inspectorate and we have selected two for intensive analysis: Huron West, on the shores of Lake Huron, and Leeds and Grenville No. 1 , in eastern Ontario. ${ }^{70}$ In 1920, women teachers in the one-room schools of these inspectorates made $88 \%$ of the salaries earned by male teachers in similar schools. In 1925, women earned $94 \%$ of male salaries; by 1930, they had near-parity, at $98 \%$. Thus in these one-room rural schools, male and female teachers, in the 1920s at least, increasingly worked for much the same wages. Moreover, throughout the decade their salaries became steadily more equitable within each certificate category. In 1920, 78\% of both male and female teachers had second-class certificates, and in this category, women earned $90 \%$ of male salaries. By 1925, 93\% of women held second-class certificates and they earned $94 \%$. And by 1930, the gap between male and female teachers with such qualifications had all but closed: women in the oneroom schools earned $99 \%$ of male wages. ${ }^{71}$

These figures, we suggest, indicate that the gender of teachers in the one-room schools in these two inspectorates was not a significant factor influencing the amount of their salaries. Perhaps these two inspectorates are unrepresentative even for Ontario, though in one Saskatchewan school district where we have located a long run of records for the teachers in its one-room school, the same thing holds true: the district changed teachers near-annually and young men were paid no more than young women holding similar qualifications. ${ }^{72}$ It is probably an act of unjustifiable bravado to generalize from three local examples to a national pattern. On the other hand, it may be indicative, and if so, certainly not trivial. The vast majority of rural schools in Canada were one-room schools, there were very large numbers of them throughout the first half of the twentieth century, and it is at least plausible to suggest that as far as salaries were concerned, there was little gender-patterning in these schools. ${ }^{73}$

The moment one turns to the graded schools, however, the salary differences are immediately apparent. And this is not simply true of the larger towns and cities. The differential existed in our two Ontario inspectorates: even in the two- or threeteacher rural schools, male principals not only made more than female assistants but usually more than female principals in other rural multi-grade schools. In 1920, for example, women principals with second-class certificates earned $81 \%$ of the salaries of their male counterparts; in 1925, the gap was decreasing, at $86 \%$, but it was still greater than in the one-room schools. By 1930, all male principals and half the female principals held first-class certificates; the women earned $91 \%$ of their male counterparts' salaries; the other women principals, with class II certificates, still earned less. In the towns in these two inspectorates, the salary differences between men and women were, on average, even greater. ${ }^{74}$

This micro-study fits the pattern documented throughout this paper and by many others as well. Simply put, across the period and regardless of the size of the urban community, male teachers on average made more than women. This does not mean 
that there were not plenty of individual women who made more than their male counterparts. Salary schedules might routinely give the advantage to better-qualified and more experienced women, and while the majority of principals were male, there were far more women principals and vice-principals than is often recognized. ${ }^{75}$ But, on average, men made more than women with identical qualifications and levels of experience. Not only did most salary schedules incorporate these differentials but often they allowed men to reach the top of their grid faster than women. ${ }^{76}$ The differentials, moreover, were not modest and most increased over time and according to the size of the community. ${ }^{77}$ Our own survey of the evidence throughout the period largely confirms what one DBS statistician concluded when surveying gender-based salary differentials across the country in 1931:

...There is very little difference between the salaries paid to men and women in rural schools - less than 10 per cent as a rule. The same is true as regards the relation between male and female teachers with lower grade certificates, and tends to be the same for those who have little or no experience. But the salary advantage of the men increases as the grade of certificate and length of experience rises. That is, considering their remuneration only, there is considerably more encouragement for men to remain in the profession and to improve their standing than there is for women. The men who raise their certificates and continue teaching long enough to secure places in urban schools enjoy a salary advantage over the women of more than 50 per cent on the average. ${ }^{78}$

How to explain these gender-based differentials? A generation of feminist scholarship has offered persuasive answers: women generally earned less than men because their services were less valued, supervisory work was considered the special prerogative of men, and the breadwinner ideal underwrote higher wages for men. Women also faced a highly competitive labour market. Though widening somewhat over the first three decades of the century, the range of employment opportunities was sharply limited to a relative handful of occupational categories, and even more so for the highly educated. ${ }^{79}$ Between 1900 and 1930 girls were more likely than boys to complete elementary school, to enter high school, and to proceed further through the grades. ${ }^{80}$ More achieved the requirements for a teaching certificate, which, depending on the decade, province, and level of qualification, ranged anywhere from grade IX or X to grades XI through XIII. ${ }^{81}$ Normal schools always enrolled far more women than men, and the number of women undergraduates also rose steadily. High turnover rates meant there were always a large number of available jobs: no school closed down because it happened to be an uneconomic unit of production; even the meanest schoolhouse with a bare quorum of children required a teacher. But periods of over-supply, or at least a comfortable balance, were more common than serious teacher shortages. In these circumstances, a large pool of qualified women inevitably kept salaries relatively low, especially in the countryside, though in urban school systems too.

Whereas women generally faced a constricted market for their education and 
skills, and women teachers a highly competitive market within their occupation, the reverse was the case for men. Given similar education credentials (and even without them), men had a much wider set of occupational choices. Even for those men who initially opted for teaching, it was often no more than a way-station, a means of earning enough money to enter university and professional training of various sorts, or to obtain enough capital to start a business or buy a farm. For those who saw their future as heads of households, able to afford marriage and a family, and to win a respectable place in society, teaching, though reasonably well paid by the late 1920s, was only one possible occupation among many, and not as attractive as many others.

This difference in markets would not have mattered much if school board trustees or the male elites in the federations and departments of education had been content to see classrooms exclusively staffed by women. Teacher efficiency was not the issue: sober-minded and experienced educators were usually willing to admit that women were equally as effective as men. ${ }^{82}$ Since efficiency was not the issue, hiring women exclusively would have made sound economic sense, allowing school boards to invest the difference in better salaries for women while still maintaining a lower overall salary budget, or applying the difference to improved programs or facilities, or lowering taxes. But economic rationality was not the prevailing factor at work. School boards usually sought out men as principals, and preferred to hire men for senior elementary school classrooms, in the belief that they were better able to maintain discipline, or, as one woman teacher, annoyed by such masculinist claims, put it, "men could probably trounce children harder and with more permanent effect." ${ }^{33}$ Another equally masculinist assumption was also at work, the view that boys needed male exemplars to ensure "vigorous manhood" and to prepare them for "nation-building." 84 Said Alberta's Deputy Minister of Education in 1920, "The teenage boy should have the leadership and direction of a manly man during the few years of his school life, and this will not be possible unless more men enter and remain in the profession." 85 Younger children were best left to women teachers, Nova Scotia's Superintendent of Education explained a little later, but "most will admit that the presence of men in the higher grades of a school system gives leadership to that part of school life more directly concerned with character-building and citizenship." ${ }^{86}$ In its Annual Report for 1933, the Winnipeg School Board took note of the fact that for some years it had "followed a policy of selecting the best available young men in the profession and adding them to the intermediate school staff. The presence in these schools of large numbers of boys at the critical adolescent period of their lives requires that this policy be continued." ${ }^{87}$ The corollary was wage discrimination in favour of men. "At first blush this may seem unreasonable," contended a coalition of British Columbia school trustees, municipal leaders, and businessmen in 1932,

but there is a wealth of argument in its favour....it is advisable for us to have men teachers for our senior boys and to act as principals. But to encourage men to enter and stay in the teaching profession, the salaries should be sufficiently attractive. Men have far more callings open to them than women. Then there is the question of marriage and family. Most men marry and their financial 
needs increase. Women teachers on marrying usually give up teaching. A married man of 35, with a small family, is worse off at $\$ 2000$ a year than a single woman at $\$ 1800$. Of course, there are always "special cases" where single women support parents and so on. But some of the married men also have aged relatives to support.... With no aspersion on the excellent work done by the women in our schools, we believe it would be unwise B on educational grounds as well as others B to adopt a Provincial scale which does not allow higher ratings for men. ${ }^{88}$

There was yet another reason why men were needed, besides the demands of the classroom. "The woman who at twenty enters on the work of a teacher is not there to stay," intoned Nathanael Burwash, president, for the year 1905, of the Ontario Educational Association: "In nine cases out of ten she marries before she is thirty; and her transient occupation of the teacher's desk leaves little permanent result upon the status of the profession. In fact, next to remuneration, permanence is one of the most important factors in determining social status." ${ }^{89}$ Nearly forty years later, Leonard Marsh would remark that "the typical age-composition of an occupation or class, perhaps unconsciously, is one of the elements which adds to or detracts from its esteem" in the social order. ${ }^{90}$ Because most women (like most men, it should be noted) left teaching at a relatively early age they contributed, simply because of their numbers, to the image of an occupation as one characterized by, and primarily fit for, transient young people, novices of limited skill or claims to expertise. This was a direct challenge to leading educators' own self-image as professional men, adults practising an occupation that required, like other professions, specialized knowledge, skills, and expertise. "The presence of male teachers in the schools enhances the standards of the profession," said one; "The male teacher stands for permanency in the profession," said another. ${ }^{91}$

The problem was that there were never enough men to sustain such assumptions. Between 1900 and the late 1920s, the leadership in Canadian education watched with dismay the steady drain of men out of teaching in favour of other, more remunerative occupations. Complaints on this score were common even before $1914 .{ }^{92}$ But military service and better pay in other occupations drew large numbers of men away from teaching during the Great War. Canada-wide, the percentage of males dropped from $20 \%$ before the war to $15.5 \%$ in its later stages. ${ }^{93}$ By 1925 the proportion of males had returned to its pre-war figure but it proved impossible to raise it above $20 \%$, and the drain appears to have been greatest in the secondary sector, which to 1914 had been the last bastion of male dominance in the teaching corps. ${ }^{94}$ This was seen as particularly problematic since it meant the loss of the most highly educated men and of those who provided the pool from which the leadership in urban and provincial school systems was mostly drawn. Salaries were too low to encourage able young men to enter the occupation, or to entice them to make it a career. "It is essential to retain in the schools a substantial percentage of highly trained, enthusiastic men teachers," the editor of the Western School Journal wrote on one occasion: 
The only way to secure men is to offer them, if of equal qualification with women, a higher salary. They cannot afford to come in at the same salary that a woman of the same qualification can afford to accept. The family wage offered is too low for the man, but suits the woman. The "equal pay" must steadily fall and must exclude men with families to support. ${ }^{95}$

Thus for reasons ranging from pedagogical imperatives to the professionalization projects of schoolmen, salary differentials were not just an inevitable outcome of different labour markets in teaching, but were deemed essential prerequisites for the vision of the good school system held by school trustees and schoolmen alike. There was no shortage of arguments in favour of equity, during the 1920s especially; but the "man problem" always trumped equity issues. It was this, we suggest, that explains the reiterated complaints about low salaries across the first three decades of the century. Whether explicitly or implicitly, the rhetoric, with near-invariable consistency, identified the problem as low salaries for male teachers. ${ }^{96}$ And it arose not out of hard-nosed comparisons of relative standing or market analysis but from preconceptions about what the occupation should be: not exclusively male certainly, but attractive enough to sustain a large cadre of male career teachers with salaries adequate to support a family in some degree of comfort, and a place in society equal to others in business or professional life.

\section{III}

Looking back at the debâcle of the Great Depression from 1940, Canada's Royal Commission on Dominion-Provincial Relations (the Rowell-Sirois Commission) would cast its eye across the spectrum of public spending by the nation's provinces and municipalities, and remark that "education bore the brunt of depression retrenchment....total expenditure is still...some \$10 million below the 1930 peak..." ${ }^{97}$ While the schools experienced a variety of spending reductions in programs and facilities, it is not too much of an exaggeration to rephrase Rowell-Sirois: in education, teachers bore the brunt of depression retrenchment.

There were two reasons for this. On the one hand, salaries constituted the bulk of operating expenses in the annual budgets of school boards: if substantial reductions had to be made, they were not possible without salary cuts. Teachers, on the other hand, were a peculiarly vulnerable target during the depression because of mounting over-supply. Experience levels rose sharply during the 1930s, and teachers who had jobs clung to them as never before. But as alternative employment opportunities for young people declined, and as other forms of post-secondary education that required large investments became unaffordable, successive crops of high school graduates crowded into the normal schools. Though numbers would gradually shrink in later years, normal school enrolments in Ontario stood at just over 2,000 in 1932 and 1933, in the following year, 1,600, and a thousand the year after that. ${ }^{98}$ Alberta issued nearly 1,100 new teaching certificates in 1931, and 800 in each of the next two years; Saskatchewan expected 1,200 new graduates in 1931 alone. ${ }^{99}$ Authorities 
in Nova Scotia noted, with a certain satisfaction, the increase in enrolments among young men: "With so many industrial doors closed to them, they are turning to the schools." ${ }^{100}$ A less sanguine interpretation was offered by one woman writing to a prairie newspaper: men, who had avoided teaching before the depression because the salaries were too low, were now "trying to put women out of their traditional jobs." 101 Beyond that, worried federation leaders took note of the number of "re-entrants," "persons who had left the profession in better times for more remunerative occupations" but had since lost their jobs or failed in business. ${ }^{102}$ In parts of rural Canada there was a marked increase in married women applying for schools, in many cases attempting to compensate for the collapse of family farm incomes. ${ }^{103}$ Altogether a large surplus of qualified teachers developed, desperate to obtain jobs in the schools and often willing to underbid those who already held them. And that, given the state of municipal finance, was a certain recipe for salary cuts.

These were of two kinds: in the countryside, ad hoc adjustments downwards, district by school district, as local revenues dried up and applicants multiplied; and in urban communities, salary freezes for years at a time, or, in many cases, acrossthe-board reductions in salary schedules. But one way or another, in current dollars at least, average salaries declined everywhere. It is not easy to ascertain the extent of the reductions in urban areas: in most cases they were cumulative over several years, in some communities they were restored or partially restored by the mid-1930s, and they often differed for elementary and secondary teachers or at different points in the salary schedule. But over the period 1929 to 1933 , cuts of $20 \%$ or $30 \%$ appear to have been common. In Calgary they ranged from $20 \%$ to over 33\%; in Vancouver, $23 \%$ to 31\%; Winnipeg, 15\% to 25\%; Saint John, 23\%. A series of reductions between 1930 and 1933 in Prince Albert's seven public schools amounted to $40 \%$ - the board saved $\$ 16,000$ in expenditure with no dismissals as a trade-off. ${ }^{104}$ That tended to be a general rule in urban Canada: smaller salaries and in many cases heavier workloads, but few teachers actually losing their jobs through staff reductions.

While school boards had to bite the bullet everywhere, the pressures were most severe in the countryside. ${ }^{105}$ Measuring pre-depression highs against depression lows, the DBS calculated that urban salaries in British Columbia had declined by about $12 \%$ and rural salaries about 16\%; for Alberta it was 9\% and 28\%; in Manitoba, $17 \%$ and $37 \%$; in Ontario, $7 \%$ and $28 \%$; in New Brunswick, $3 \%$ and $20 \% .{ }^{106}$ Such figures are, however, provincial averages, incorporating different types of schools and varying local economic circumstances. In Manitoba's one-room schools the cumulative cut from 1931 to 1934 was over 42\%. ${ }^{107}$ Between 1930 and 1935, salaries in Ontario's Huron West inspectorate declined by $18 \%$ for men and $11 \%$ for women in the towns; in the rural one-room schools, by $44 \%$ and $40 \%$ respectively. In Leeds/ Grenville inspectorate, the cuts in the towns were 31\% for men and less than $1 \%$ for women, but in the rural one-room schools, $38 \%$ and $42 \%$ respectively. ${ }^{108}$

With one or two exceptions, the depression did little to alter salary differentials among the provinces. British Columbia and Ontario remained at the top of the heap, and while the rich got a little poorer, the gaps were nothing short of astonishing. In 1933 British Columbias teachers earned, on average, $\$ 1,416$ in current dollars; in 
Nova Scotia, it was \$741; in New Brunswick, \$628; in Prince Edward Island, \$551 (Table 3). And though teachers in rural Manitoba and parts of Alberta were also hit hard, Saskatchewan is a story of its own. In 1930, total teachers' salaries stood at $\$ 8$ million; by 1934 that figure had fallen to less than $\$ 4$ million. The amount paid to rural teachers declined in the same period from $\$ 4,537,000$ to $\$ 1,939,000$, a decrease of about 68\%. ${ }^{109}$ Saskatchewan, which had paid its teachers relatively well in the 1920 s, fell to Maritime levels in the 1930s. Consider Kipp School District No. 1589, about halfway between Regina and Saskatoon. In this hitherto modestly prosperous rural school district, the Kipp trustees had paid their teachers $\$ 1,100$ per annum in the late 1920 s. In 1931 , they were paying $\$ 600$; in $1932, \$ 500$; in $1933, \$ 200$, the amount of the government grant, which was the only portion they could guarantee. In 1936 they offered \$350 "plus increase if funds can be collected from municipality." Yet that year "there were 45 applications for the school." By 1939 the trustees felt able to pay $\$ 500$, less than half the amount a decade earlier. And with but a single exception, every one of the Kipp teachers, from 1929 through 1939, held first-class certificates. ${ }^{110}$

In some parts of rural Canada, teachers were lucky to get paid at all. In Nova Scotia, said one report, "arrears in teachers' salaries reached their maximum of $\$ 187,000$ in 1936." "The same year, in Alberta, they amounted to $\$ 304,000 .{ }^{112}$ Predictably, it was even worse in Saskatchewan: by 1935 , arrears exceeded $\$ 850,000$ and by 1937 , they were just over $\$ 1,207,000 .{ }^{113}$ In a survey of representative school districts carried out near the end of the decade, two inspectors reported that half the teachers in their areas were in arrears of salary; when, in 1938, 89 teachers assembled at Weyburn to report on their situation, "there were 13 with arrears of salary accumulated prior to January 1, 1935, 34 received no salary for the term from January to June 1938 until the month of June, and 22 received less than $\$ 50$. On June 30, 15 had received less than $\$ 100$ and 20 less than $\$ 200$." Forty of the 89 teachers were under contract for less than $\$ 500$, and one for less than $\$ 400 .{ }^{114}$

All of this is but to say that teachers bore their share of human misery wrought by the depression. But then they were not alone. The children they taught, the parents of those children, and other ratepayers suffered as well. This was particularly the case among those who depended for their incomes on Canada's primary industries, namely fishing, farming, forests, and mining. These were, par excellence, the revenue bases for rural and small-town communities across the country, one or other of them, indeed, often the singular base. And the money to pay rural teachers' salaries came directly, and in most provinces overwhelmingly, out of the pockets of the people who lived in those communities. ${ }^{115}$ The reason that rural teachers paid the price they did during the depression was painfully simple: too many rural people could not afford to pay all or some of their property taxes and, at the same time, feed their families.

Sometimes in contemporary commentary, and occasionally in the work of historians, one finds a tendency to treat rural trustees and ratepayers as mean-spirited skinflints willing to pinch pennies at the expense of the easiest target they could find, 
the young women they hired as teachers. There were undoubtedly such instances; but caricatures hardly do justice to the plight of rural Canada, or the bitter realities of local finance, during the 1930s. "At the bottom of the depression," the Rowell-Sirois Commission noted, "the average price of Canadian fish was cut in half; the price of dried cod was down nearly 70\%." 116 In the Maritimes, "while total farm income, including income in kind, fell by half from 1928-32, net cash income fell by fourfifths." 117 "Unless times change for the better," wrote Nova Scotia's school inspector for Cape Breton East in 1933, "not only free books but free clothing will become an absolute necessity in cases where parents, through no fault of their own, have long been without any remunerative work." His inspectorate, he continued,

consisting to a large extent of fishing and mining communities, has felt the depression perhaps more than many other parts of Nova Scotia. Fishermen in my district, for instance, have frequently excused the backwardness of their school finances by stating that they had been unable to market their fish. Naturally I could not show them how. Likewise the market for coal during the past school year has been an exceedingly poor one. And if the towns and villages throughout the inspectorate cannot sell they cannot purchase and further they automatically pass both disabilities on to the surrounding farmers of the rural sections. ${ }^{118}$

On the prairies, Rowell-Sirois noted, total income "fell almost by half, and income from agriculture by almost four-fifths, from the 1926-28 average to the 1930-37 average." Then, in a rare departure from its normally dispassionate prose, the commission added, "These basic statistics, however, cannot convey the full measure of the Western debâcle with its shattering blows to living standards, to adequate nutrition, to health services, to educational standards, to community equipment such as highways, and to individual hopes and dreams and ambitions." 119 The historian of the Canadian prairies, Gerald Friesen, writes that "the crisis was worst in the wheat belt of Saskatchewan where, by the end of the terrible crop failure of 1937, it was estimated that two in three members of the farm population were destitute." ${ }^{20}$

Viewed from this perspective, just how badly were teachers served during the depression? Again, Rowell-Sirois:

On average, employed wage earners and persons receiving salaries suffered no reduction in real income. Most of the workers in the skilled trades, the professions and white-collar occupations who retained their jobs actually enjoyed a considerable improvement in their real position. The losses were completely borne by the 500,000 to 600,000 unemployed...by the farm and other primary producers, and by [those]...who received the profits from industry and trade. $^{121}$

Unlike many other occupations, there was no reduction in the total number of teaching jobs available. ${ }^{122}$ Salary reductions were common among all those who worked 
for public authorities, no less than teachers. But most important here, those teachers who remained employed benefited from the massive price deflation occasioned by the depression. ${ }^{123}$ Between 1929 and 1933, in constant dollars, average salaries - and it is important to emphasize we are referring to averages - went up, not down: that is, in terms of purchasing power, teachers, on average, were better off in 1933 than in 1929, in some provinces substantially better off; only in Saskatchewan did constant dollar averages decline across these years (see Table 2 and appendix, Table A2). Nationally, and again, on average and in constant dollars, teachers' earnings rose from $\$ 1,400$ in 1929 to $\$ 1,675$ in 1933 , though as the economy revived the figure began to slip back, to $\$ 1,474$ in 1938 for example. ${ }^{124}$ According to the CTF's analysis, from 1929 until about 1939, teachers' salaries remained well above the average for "all persons in the Labour Force receiving income." ${ }^{125}$ In most provinces teachers' earnings maintained a place somewhere between that of wage-earners and salaried employees in the manufacturing industries; in some provinces they improved the rank they held in the late 1920s (see Table 4). ${ }^{126}$ And while, in current dollars, teachers' average salaries fell between 1929 and 1933 from $\$ 1,061$ to $\$ 985$, wage-earners saw a decline from $\$ 1,073$ to $\$ 777$. Among the self-employed, farmers experienced a drop from $\$ 599$ to $\$ 158 .{ }^{127}$ When rural folk grumbled about the salaries young women teachers earned, or cut their wages to the bone, they had, according to their own lights, some good reasons. In a fine article recounting her mother's experience as a young teacher in rural Nova Scotia during the 1930s, Dianne Hallman writes that out of a typically meagre salary in rural Nova Scotia,

my mother paid three to five dollars a week for board ( $\$ 120$ to $\$ 200$ a year for a 40 -week school year). She generally spent summers at the home of her parents. Being a single woman with no dependents, she was able to save enough in three years to buy a car, and from then on, often travelled to her parents' home for weekends. She found the pay low, but reasoned that "men in the thirties (labourers) with families worked at any kind of work they could get for $\$ 1.00$ a day, often walking several miles to and from jobs." Like [other women] she was "grateful to be working." 128

And even in desperate times, companies like Holt Renfrew, Canadian National Railways, and Greyhound thought it worthwhile to advertise regularly in the educational press for stylish clothing and national and international holiday travel. ${ }^{129}$

For the leadership in Canadian education, the depression appeared to produce some good omens, initially at least. During the 1930s, the proportion of men in the teaching force rose from $20 \%$ to $30 \%$, higher than it had been for decades. ${ }^{130}$ Experience and qualifications, moreover, rose sharply over the decade for both women and men. ${ }^{131}$ Comparatively speaking, teaching was one of the good jobs to have during the depression so there was far less turnover than in earlier years, while over-supply allowed provincial departments of education to raise normal school entry standards substantially, and even rural trustees could pick and choose among candidates as never before. Any optimism these changes generated, however, turned out to 
be little more than whistling in the dark. By 1940 the men began to disappear and women were flooding out of the occupation as well. A catastrophic teacher shortage was in the making, and emergency teacher-training programs were welcoming candidates who would have been pre-emptively refused admission on academic grounds only a few years earlier. Moreover, by the late 1930s, in constant dollars, teachers were already losing ground, while the 1941 census revealed sharp declines in their relative standing compared to other occupations. ${ }^{132}$ The decline for men, however, was greater than for women (compared to other male and female occupations respectively). Which elicited the predictable response: in a 1940 bulletin produced by the Canadian Teachers' Federation, the entire weight of analysis fell upon men's earnings and the call was for salaries that would "permit men teachers to have homes and raise families in modest comfort conforming to the society in which they live." ${ }^{133}$ It was only over the next two decades, and under the influence of quite different social and economic circumstances, that the terms of complaint about low salaries would shift from the minority of men to encompass the entire occupation. ${ }^{134}$

By way of conclusion, several points deserve attention. First, we hope we have made the point that national and provincial averages can be useful, but it is a mistake to treat the occupation as an undifferentiated mass. Teaching was a highly segmented occupation, stratified by levels of qualification and experience and by geography (urban, rural, regional). This indeed applies to gender as much as to our other category distinctions. There was a world of difference between the young woman putting in a handful of years between adolescence and marriage, the young man teaching for a couple of years to save up enough money for medical or law school, and those women and men whose careers led them from the one-room school to a lifetime of service in Vancouver, Winnipeg, or Halifax (not to say, in the case of our two Ontario inspectorates, Goderich or Gananoque). ${ }^{135}$

Second, as far as salaries are concerned, the historical moment matters. Teachers, all and sundry, took an economic beating during the Great War, and many shared the pain of the Great Depression. Teachers in the west benefited from desperate shortages before 1914 but did not gain much ground in the twenties when supply began to meet demand. Large enrolment increases guaranteed high levels of job security during the depression for secondary school teachers; declining birth-rates in the 1920s left elementary school teachers more at risk. Rural teachers on the prairies benefited from the pre-war wheat boom but paid a price with the collapse of farm prices in the early 1920s and again in the 1930s. And so on.

When we meet general complaints about salaries, moreover, we need to probe more deeply by asking just who the aggrieved parties were supposed to be, and why. In our sample of opinion, the main thrust of complaint about low salaries arose primarily from pre-conceptions about what the gender profile of the occupation should look like rather than what it was. From a purely economic perspective, after all, there was no good reason why women should not become even more numerically predominant than they already were. And the pedagogical justifications also need 
scrutiny. Except for the purported virtues of boys' character formation, nobody really argued that men were more effective in providing good teaching; and, generally speaking, women can "trounce children" as well as men, often more judiciously and to greater effect.

Finally, if we are working with averages over time it should be clear that we need to deal in constant dollars, and if we are trying to assess the relative earning power of teachers we need sound, systematic comparisons to other occupations. In this respect the article has two central conclusions. First, in terms of earning power, teachers' salaries improved over the first four decades of the century. Moreover, for those teachers who had jobs and kept them during the Great Depression, they were better off than ever before; indeed, if the CTF analysis is correct, better off than they would be throughout the 1940s and first half of the 1950s. ${ }^{136}$ Second, in urban Canada their average salaries put them firmly among the middle and lower-middle classes. The young and inexperienced, attempting to learn their craft in the nation's oneroom schools, were certainly less well rewarded; still, they received wages at least comparable to the average earnings of the rural folk who paid their salaries. Unless one believes, as nearly all members of any occupation are prone to do on occasion, that their work is definitionally under-paid and under-valued, it is hard to credit the claims that teachers were, in any singular way, ill-rewarded for their work. "On average," of course.

Our thanks to the anonymous reviewers for acute and thoughtful critical commentary, and to Michael Dawson and Catherine Gidney for careful readings of earlier drafts. 
Table 1

Average salaries of teachers, census figures, 1901, 1921, 1931, 1941

\begin{tabular}{|l|c|c|c|c|}
\cline { 2 - 5 } \multicolumn{1}{c|}{} & \multicolumn{2}{c|}{$\mathbf{1 9 0 1}$} & \multicolumn{2}{c|}{$\mathbf{1 9 2 1}$} \\
\cline { 2 - 5 } & $\mathbf{M}$ & $\mathbf{F}$ & $\mathbf{M}$ & $\mathbf{F}$ \\
\hline Canada & $\mathbf{\$}$ & $\mathbf{\$}$ & 1395 & $\mathbf{\$}$ \\
\hline & & 246 & & \\
\hline PEI & 246 & 180 & 662 & 470 \\
\hline Nova Scotia & 384 & 238 & 1148 & 577 \\
\hline New Brunswick & 413 & 228 & 1191 & 674 \\
\hline Quebec & 450 & 138 & 919 & 414 \\
\hline Ontario & 538 & 308 & 1685 & 974 \\
\hline Manitoba & 487 & 410 & 1459 & 1096 \\
\hline The Territories & 498 & 428 & & 1092 \\
\hline Saskatchewan & & & 1371 & 1069 \\
\hline Alberta & & & 1365 & 1071 \\
\hline British Columbia & 677 & 553 & 1703 & \\
\hline
\end{tabular}

\begin{tabular}{|l|c|c|c|c|}
\cline { 2 - 5 } \multicolumn{1}{c|}{} & \multicolumn{2}{c|}{$\mathbf{1 9 3 1}$} & \multicolumn{2}{c|}{$\mathbf{1 9 4 1}$} \\
\cline { 2 - 5 } \multicolumn{1}{c|}{} & $\mathbf{M}$ & $\mathbf{F}$ & $\mathbf{M}$ & $\mathbf{F}$ \\
\hline Canada & 1575 & 917 & 1416 & $\mathbf{\$}$ \\
\hline PEI & & & & \\
\hline Nova Scotia & 683 & 515 & 691 & 444 \\
\hline New Brunswick & 1152 & 633 & 1160 & 649 \\
\hline Quebec & 1223 & 701 & 1096 & 616 \\
\hline Ontario & 1167 & 507 & 1218 & 472 \\
\hline Manitoba & 2023 & 1191 & 1801 & 1092 \\
\hline Saskatchewan & 1484 & 1043 & 1173 & 856 \\
\hline Alberta & 1310 & 969 & 915 & 704 \\
\hline British Columbia & 1435 & 1083 & 1210 & 930 \\
\hline
\end{tabular}

Notes: Salaries in 1921 and 1931 are given in the source as weekly earnings; they have been multiplied by the average number of weeks employed in the year to give an annual figure since teachers were paid on an annual basis. Figures for 1911 are not available. All figures are rounded.

Sources: Census of Canada, 1901, Bulletin 1. Wage-Earners by Occupations (1907); Census of Canada, 1931, vol. V, Tables 19-22 (1921 and 1931); Census of Canada, 1941, vol. VI, Table 6. 
Table 2

Average salaries, Canadian teachers, 1910-1938, selected years ${ }^{a}$

\begin{tabular}{|c|c|c|}
\hline Year & Current \$ & Constant \$ \\
\hline 1910 & 446 & 446 \\
\hline 1920 & 841 & $413^{\mathrm{b}}$ \\
\hline 1926 & 1,019 & 596 \\
\hline 1929 & 1,061 & 622 \\
\hline 1933 & 985 & 744 \\
\hline 1938 & 939 & 654 \\
\hline
\end{tabular}

\section{Notes:}

a These are the years selected in the source.

${ }^{\mathrm{b}}$ Corrected from the original table. The Consumer Price Index given on p. 130 of the source indicates that, based on 1910, $\$ 841$ in current dollars in 1920 would have been equal to $\$ 413$ in constant dollars. We have used this constant dollar series based on 1910 in the text and all tables.

This table includes Quebec teachers.

Source: Canadian Teachers' Federation, Trends in the Economic Status of Teachers, 1910-1955, Research Study No. 2 (Ottawa: CTF, 1957), Table 1.3, p. 49. 
Table 3

Provincial Rankings, Teachers' Average Salaries, 1910-29, constant dollars and selected years

\begin{tabular}{|c|c|c|c|}
\hline 1910 & 1920 & 1926 & 1929 \\
\hline $\begin{array}{l}\text { British Columbia } \\
\quad \$ 866\end{array}$ & $\begin{array}{l}\text { British Columbia } \\
\qquad 638\end{array}$ & $\begin{array}{l}\text { British Columbia } \\
\quad \$ 837\end{array}$ & $\begin{array}{l}\text { British Columbia } \\
\quad \$ 859\end{array}$ \\
\hline $\begin{array}{l}\text { Alberta } \\
\$ 729\end{array}$ & $\begin{array}{l}\text { Saskatchewan } \\
\quad \$ 628\end{array}$ & $\begin{array}{l}\text { Ontario } \\
\$ 710\end{array}$ & $\begin{array}{l}\text { Ontario } \\
\$ 725\end{array}$ \\
\hline $\begin{array}{c}\text { Saskatchewan } \\
\$ 713\end{array}$ & $\begin{array}{l}\text { Alberta } \\
\$ 579\end{array}$ & $\begin{array}{l}\text { Manitoba } \\
\$ 707\end{array}$ & $\begin{array}{l}\text { Alberta } \\
\$ 716\end{array}$ \\
\hline $\begin{array}{l}\text { Manitoba } \\
\$ 628\end{array}$ & $\begin{array}{l}\text { Manitoba } \\
\quad \$ 466\end{array}$ & $\begin{array}{l}\text { Alberta } \\
\$ 705\end{array}$ & $\begin{array}{l}\text { Manitoba } \\
\$ 708\end{array}$ \\
\hline $\begin{array}{c}\text { Ontario } \\
\$ 485\end{array}$ & $\begin{array}{c}\text { Ontario } \\
\$ 428\end{array}$ & $\begin{array}{l}\text { Saskatchewan } \\
\$ 655\end{array}$ & $\begin{array}{c}\text { Saskatchewan } \\
\$ 682\end{array}$ \\
\hline $\begin{array}{c}\text { New Brunswick } \\
\$ 334\end{array}$ & $\begin{array}{c}\text { New Brunswick } \\
\$ 307\end{array}$ & $\begin{array}{c}\text { New Brunswick } \\
\$ 472\end{array}$ & $\begin{array}{c}\text { New Brunswick } \\
\$ 472\end{array}$ \\
\hline $\begin{array}{c}\text { Nova Scotia } \\
\$ 291\end{array}$ & $\begin{array}{l}\text { Nova Scotia } \\
\quad \$ 237\end{array}$ & $\begin{array}{l}\text { Nova Scotia } \\
\quad \$ 386\end{array}$ & $\begin{array}{l}\text { Nova Scotia } \\
\$ 422\end{array}$ \\
\hline $\begin{array}{l}\text { Prince Edward Island } \\
\$ 225\end{array}$ & $\begin{array}{l}\text { Prince Edward Island } \\
\$ 167\end{array}$ & $\begin{array}{c}\text { Prince Edward Island } \\
\$ 319\end{array}$ & $\begin{array}{c}\text { Prince Edward Island } \\
\$ 323\end{array}$ \\
\hline
\end{tabular}

Notes: Ontario: elementary school teachers. All other provinces: elementary and secondary school teachers.

Source: Canadian Teachers' Federation, Trends in the Economic Status of Teachers, 1910-1955, Research Study No. 2 (Ottawa: CTF, 1957), Tables 1.9 ff. 
Table 4

Average salaries of teachers, and of wage-earners and salaried employees in manufacturing industries, as percentage of per-capita income in each province, 1926, 1929, 1933, 1938

\begin{tabular}{|l|c|c|c||c|c|c|}
\cline { 3 - 4 } \multicolumn{1}{c|}{} & \multicolumn{3}{c|}{1926} & \multicolumn{3}{c|}{1929} \\
\cline { 3 - 4 } \multicolumn{1}{c|}{} & \multicolumn{2}{c|}{ Manufacturing } & & \multicolumn{2}{c|}{ Manufacturing } \\
\cline { 3 - 4 } \multicolumn{1}{c|}{} & Teachers & $\begin{array}{c}\text { Wage- } \\
\text { earners }\end{array}$ & Salaried & Teachers & $\begin{array}{c}\text { Wage- } \\
\text { earners }\end{array}$ & Salaried \\
\hline British Columbia & $275 \%$ & $205 \%$ & $366 \%$ & $249 \%$ & $188 \%$ & $338 \%$ \\
\hline Alberta & 250 & 231 & 381 & 288 & 253 & 431 \\
\hline Saskatchewan & 256 & 269 & 400 & 379 & 370 & 576 \\
\hline Manitoba & 258 & 246 & 400 & 268 & 261 & 426 \\
\hline Ontario & 245 & 215 & 380 & 218 & 195 & 351 \\
\hline New Brunswick & 294 & 264 & 694 & 271 & 251 & 636 \\
\hline Nova Scotia & 228 & 238 & 546 & 219 & 233 & 546 \\
\hline PEI & 251 & 112 & 383 & 212 & 111 & 365 \\
\hline
\end{tabular}

\begin{tabular}{|l|c|c|c||c|c|c|}
\cline { 3 - 4 } \multicolumn{1}{c|}{} & \multicolumn{3}{c|}{1933} & \multicolumn{3}{c|}{1938} \\
\cline { 3 - 4 } \multicolumn{1}{c|}{} & \multicolumn{2}{c|}{ Manufacturing } & & \multicolumn{2}{c|}{ Manufacturing } \\
\cline { 3 - 4 } \multicolumn{1}{c|}{} & Teachers & $\begin{array}{c}\text { Wage- } \\
\text { earners }\end{array}$ & Salaried & Teachers & $\begin{array}{c}\text { Wage- } \\
\text { earners }\end{array}$ & Salaried \\
\hline British Columbia & $400 \%$ & $251 \%$ & $439 \%$ & $306 \%$ & $241 \%$ & $380 \%$ \\
\hline Alberta & 552 & 436 & 732 & 301 & 294 & 444 \\
\hline Saskatchewan & 635 & 695 & 997 & 320 & 480 & 638 \\
\hline Manitoba & 413 & 350 & 617 & 282 & 311 & 497 \\
\hline Ontario & 368 & 240 & 494 & 246 & 219 & 392 \\
\hline New Brunswick & 302 & 391 & 865 & 296 & 348 & 670 \\
\hline Nova Scotia & 356 & 336 & 596 & 268 & 296 & 482 \\
\hline PEI & 414 & 349 & 576 & 281 & 253 & 410 \\
\hline
\end{tabular}

Notes: Ontario: elementary school teachers. All other provinces: elementary and secondary school teachers.

Source: Canadian Teachers' Federation, Trends in the Economic Status of Teachers, 1910-1955, Research Study No. 2 (Ottawa: CTF, 1957), Tables 1.9 ff. 


\section{Notes}

1 For examples of both see British Columbia, Survey of the School System, by J.H. Putman and G.M. Weir [Putman-Weir Report] (Victoria: King's Printer, 1925), 189-92; Alberta Committee on Educational Costs, quoted in The Manitoba Teacher IX, 7 (Sept. 1928): 12; J.D. Wilson, "II am ready to be of assistance when I can': Lottie Bowron and Rural Women Teachers in British Columbia," in Women Who Taught: Perspectives on the History of Women and Teaching, ed. Alison Prentice and Marjorie R. Theobald (Toronto: University of Toronto Press, 1991), 206; Eric W. Sager, "Women teachers in Canada, 1881-1901: Revisiting the 'Feminization' of a Profession," Canadian Historical Review 88, 2 (June 2007): esp. 224-33.

2 Though the nineteenth-century literature poses broader questions than those focusing on salaries alone, teachers' earnings usually comprise a part of the discussion of the changing structure of the occupation. The recent article by Eric Sager provides a broadbased set of references and a historiographical introduction to this body of work so we forgo further commentary here. But we would be remiss if we did not also acknowledge the pioneering work of Alison Prentice on nineteenth-century teachers, both men and women. See Sager, "Women teachers in Canada," passim. There is however only scattered work on teachers' earnings in the first half of the twentieth century and no extended national-level survey. Patrick Harrigan has touched briefly on one aspect of the many issues we raise here about salaries, that is, on male-female salary differentials, in "The Development of a Corps of Public School Teachers in Canada, 1870-1980," History of Education Quarterly 32, 4 (Winter 1992): 514-17. There is nothing especially significant about 1900, our own point of departure, beyond the fact that during the first decades of the century useful national-level quantitative data begin to become available. We close in c. 1940 simply because the decades that follow pose new issues, and different kinds of problems, than those we are concerned with here.

3 For the sources and commentary on the figures cited in this paragraph see section 6 of the appendix.

4 We review and comment on each of these basic sources in section 1 of the appendix.

5 As work on the nineteenth century by several historians has shown, and most recently on 1901 by Eric Sager, "Women teachers in Canada," there is no substitute for analysis at the household census level, not only for salary issues but for the context of individual teachers' lives. The census microdata samples for 1911 to 1951, soon to be available through the Canadian Century Research Infrastructure Project, will provide a wealth of material for such work. Many of the essays cited in our references also use oral history, diaries, and other such records to illuminate individual experience and circumstances.

6 See Putman-Weir Report, 270; The School 9, 1 (Sept. 1920): 54 (Manitoba); Ontario, Department of Education, Annual Report 1939, 174 (graph 8, 1900-38); Ontario, Department of Education, Annual Report 1946, 110 (Ontario average salaries, annually, 1902-47) [hereafter we will cite all provincial department of education and city board of education Annual Reports as $A R]$.

7 For further commentary on regional patterns, and a table providing province-byprovince salaries in both current and constant dollars to match the national data in Table 2, see section 7 and Table A2 in the appendix.

8 Dominion Bureau of Statistics [DBS], Annual Survey of Education in Canada, 1929 [Annual Survey 1929], xv. The analysis applied specifically to Ontario, but the experts thought the situation was probably much the same elsewhere in Canada. We think it plausible, however, that the percentage might have been somewhat greater in the west, given that in 1913 the western shortage of teachers meant that proportionately more with third-class certificates or teaching on permits got jobs there, compared to the east; in the 1920s, third-class and permit teachers disappeared virtually everywhere. See the appendix, note 2 , for the various titles of DBS surveys of education. 
9 For sources and commentary on teacher certification and supply, see appendix, section 8.

10 On the terms "wages," "salaries," and "earnings," see our commentary in the appendix, section 12.

11 Census of Canada, 1901, Bulletin 1. Wage-Earners by Occupations, xx and Table II.

12 Sager, "Women teachers in Canada," 228-29.

13 The figures are: clergy, \$712; government employees, \$829; engineers, \$1,306. Census of Canada, 1901, Bulletin 1. Wage-Earners by Occupations, xx and Table II.

14 Sager, "Women teachers in Canada," 228.

15 Canadian Teachers' Federation [CTF], Trends in the Economic Status of Teachers, 1910-1955, Research Study No. 2 (Ottawa: CTF, 1957), Table 1.3, 49. INLF is a national figure (including Quebec); though the CTF study uses it for provincial comparisons as well, it is less satisfactory for that purpose. See the discussion of various measures in ibid., 16-18.

16 For the other provinces, the figures were: Alberta, 113\%; Saskatchewan, 111\%; Manitoba, 97\%; Quebec (teachers in Protestant schools), 58\%; New Brunswick, 52\%; Prince Edward Island, 35\%. See CTF, Trends, Tables 1.3 through 1.42, pp. 49-68.

17 David Stager, "Elementary and Secondary School Teachers' Salaries in Ontario, 1900 to 1975," paper prepared for The Commission on Declining School Enrolment in Ontario (March 1978, typescript), 18.

18 Miller, Rural Schools, 64-65. For a similar assessment made a few years earlier by Nathanael Burwash, see "The Social Status of the Teacher," Proceedings of the... Ontario Educational Association [Proceedings, OEA], 1905, 72-74.

19 The figures for all teachers were: British Columbia 98\%, Alberta 89\%, Saskatchewan 97\%, Manitoba 72\%, Ontario 71\%, Quebec (teachers in Protestant schools) 69\%, New Brunswick 47\%, Nova Scotia 37\%, Prince Edward Island 26\%. See CTF, Trends, Tables 1.3 through 1.42 , pp. 49-68.

20 For the figures in this paragraph see Census of Canada, 1931, vol. V, Table 20 [1921 figures]. It is important to note that there are changes in relative annual earnings when the annual number of weeks employed in each occupation is considered. See the appendix, section 13, for our commentary on weekly wage figures in the 1921 and 1931 censuses.

21 The average weekly salary of female teachers in Ontario was $\$ 19.37$; Alberta, $\$ 21.70$; British Columbia, \$21.69; Nova Scotia, \$11.47.

22 However, they included, in their estimates of wages for nurses, domestic servants, and store clerks, such items as board, lodging, laundry, and store discounts; if one could adjust the figures, teachers' wages would probably compare much more favourably with those earned by nurses and clerks, and be well above the wages of domestic servants. See Manitoba, Report of Commission on Status and Salaries of Teachers (Manitoba 1919), 14-15.

23 DBS, Annual Survey 1926, xii. The only instance in which teachers made less was in the age category of 20-24, for male teachers (a minor difference, $\$ 19.74$ compared to $\$ 20.83)$. Otherwise salaries for teachers remained greater in all age categories, male and female alike; ibid., xii-xiii.

24 See Stager, "Teachers' Salaries," 12, for a similar comparison, in this case with the average annual earnings of all occupations in Canada. Male teachers' salaries stood at $170 \%$ of the average occupational earnings in 1931; female teachers' salaries, at $164 \%$. In Ontario the relative earnings were $201 \%$ for men and $187 \%$ for women. However, this does not enlighten us about teachers' salaries versus those of other individual occupations.

25 Census of Canada, 1931, vol. V, Table 19. Using the 1931 census as an additional indicator for the late 1920s has the obvious problem that it begins to reflect the 
deteriorating effects of the depression. On the other hand, so did the wages of many other workers and our emphasis here is on the comparative figures and not on net gains or losses experienced by teachers. See also our additional commentary in the appendix, section 16.

26 Constant dollars and INLF figures from CTF, Trends, relevant tables.

27 Stager, "Teachers'Salaries," 18 (elementary school teachers).

28 Women, who were paid, across the board, far less than men, constituted only $20 \%$ in 1921 and 22\% in 1931 of the general workforce. See Morris Altman and Louise Lamontagne, "On the Natural Intelligence of Women in a World of Constrained Choice: How the Feminization of Clerical Work Contributed to Gender Pay Equality in Early Twentieth Century Canada," Journal of Economic Issues XXXVII, 4 (Dec. 2003): 1049 .

29 In 1921, those aged $15-24$ constituted $26.6 \%$ of all "gainfully employed" in Canada; the figure for all teachers under 25 was $45.6 \%$. This contrast between the general and teaching workforce had not changed since 1911 (29.4\% and 48.3\% respectively) and would remain substantial in 1931 (27.1\% and $39.2 \%$ respectively). For the sources and further comment here see the appendix, section 9.

30 Miller, Rural Schools, 65.

31 H.W. Foght, A Survey of Education in the Province of Saskatchewan (Regina: King's Printer, 1918), 104-13. The percentages are our calculations.

32 George Perry, “'A Concession to Circumstances': Nova Scotia's 'Unlimited Supply' of Women Teachers, 1870-1960," Historical Studies in Education 15, 2 (Fall 2003): 340, figure 4.

33 Ontario, $A R$ 1911, 26, and $A R$ 1921, 124.

34 Our calculations from DBS, Annual Survey 1931, 75-80 (Nova Scotia, New Brunswick, Manitoba); DBS, Annual Survey 1932, 76-77 (Ontario data for 1931). For a closer examination of experience levels in two Ontario inspectorates, see the appendix, section 15.

35 BC Teacher XII, 4 (Dec. 1932): 38 (figures for 1931; our calculations).

36 See CTF, Trends, 26.

37 Our calculations from Leonard C. Marsh, Canadians In and Out of Work: A Survey of Economic Classes and Their Relation to the Labour Market (Oxford: Oxford University Press, 1940), Table 29, 166.

38 Ibid., 167.

39 Marsh, for example, lists "copywriters, buyers, dress designers" in the "upper commercial group"; ibid., 189.

40 Ibid., 180 and 182.

41 Marsh points out emphatically that in measuring earnings, "the degree of regularity of employment is just as important in setting income levels as the wage rate, if not more so." Ibid., 178-79 [italics in original]. Teachers were normally hired on an annual contract, or for a full term with a salary prorated on an annual basis.

42 See DBS, Annual Survey 1928, xxxix-xliii.

43 Marsh, Canadians In and Out of Work, 178-80. His table of "unit earnings" for women by occupational class, p. 179, makes the point graphically. Teachers are not named separately but they make up the majority of those in the professional group.

44 See William L. Richardson, The Administration of Schools in the Cities of the Dominion of Canada (Toronto: J.M. Dent, 1922), 161; Putman-Weir Report, 404; R.M. Stamp, School Days: A Century of Memories (Calgary: Calgary Board of Education, McClelland and Stewart West, 1975), 44; Winnipeg Public School Board, AR 1920, 39; Saskatchewan, $A R$ 1927, 96 (Regina).

45 For salary grids established in various Canadian cities early in the century and for an analysis of the principles around which they were organized, see Richardson, Administration of Schools, 173-81. 
46 While most high school teachers had university degrees, the smaller high schools especially had teachers with senior matriculation standing (equivalent to first-year university), which, combined with a year's professional training, provided the highest level of elementary teaching certificate and, depending on the decade, allowed them to teach high school in most provinces.

47 Retrospective salary table, Ontario, $A R$ 1946, 110. Similarly, in the mid-1920s median salaries in British Columbia were $\$ 2,412$ for high school teachers and $\$ 1,372$ in city elementary schools: Putman-Weir Report, 190.

48 The figures are for "grammar school" teachers, which does not include all town high school teachers. DBS, Annual Survey 1926, 90. For Saskatchewan see, for example, DBS, Annual Report on Education Statistics 1922, 132, and DBS, Annual Survey 1930, 68. For comparative figures for eight cities, selected years from 1910 on, see CTF, Trends, Tables $1.46 \mathrm{ff}$.

49 The figures for minimum and maximum salaries in this and the next paragraph are from CTF, Trends, relevant tables.

50 Marsh, Canadians In and Out of Work, table on p. 166.

51 Ontario, $A R$ 1929, 130-31. In 1930, 74\% of male teachers in Ontario cities had six or more years of experience, and so did $76 \%$ of women teachers; these average salaries therefore are pertinent figures for most urban teachers. See Ontario, AR 1930, 142.

52 Marsh, Canadians In and Out of Work, 166-68.

53 For two examples of average salaries in the mid-1920s in village schools see DBS, Annual Survey 1926, 95 (Alberta); Nova Scotia, AR 1924, 18-21. For an illuminating analysis of persistent regional price and wage disparities across Canada in the first half of the twentieth century, see J.C. Herbert Emery and Clint Levitt, "Cost of living, real wages and real incomes in thirteen Canadian cities, 1900-1950," Canadian Journal of Economics 35, 1 (Feb. 2002): 115-37 and esp. Table 4, p. 135.

54 The School 21, 4 (Dec. 1932): 357 (Alberta); New Brunswick, AR 1919-20, xiv, and J.E. Picot, A Brief History of Teacher Training in New Brunswick, 1848-1973 (Fredericton: Department of Education, N.B., 1974), 67. Nova Scotia legislated a minimum salary in 1919: see Nova Scotia, $A R$ 1918, xv, and $A R$ 1919, xvii-xviii. Ontario achieved the same end through regulation, by making the township grant dependent on a minimum salary of $\$ 500$.

55 Manitoba Teachers'Federation, Bulletin No. 28, Dec. 1923, 495. See also Western School Journal [WS] XXV, 3 (March 1930): 110; Robert England, The Central European Immigrant in Canada (Toronto: Macmillan, 1929), 119; J.W. Marshall, "Rural School Problems," Proceedings, OEA, 1915, 318. The Manitoba Commission of 1919 observed that "it is in the cities and towns where teachers are found with ten, twenty or thirty years of experience. The rural schools as a rule have young and inexperienced teachers. The majority of third class teachers are employed in the rural schools and the experience of most teachers of that grade is three years"; Manitoba, Report of Commission...Salaries of Teachers, 11.

56 Alberta, $A R$ 1906, 22. The figures are for 1905.

57 Rural women teachers with first-class certificates earned a lower average salary B \$788 B than their less-well-qualified urban sisters. Saskatchewan, AR 1915, 20.

58 Putman-Weir Report, 190.

59 Nova Scotia, AR 1929, xv.

60 Salary tables in Ontario, $A R$ 1926, 77, and Ontario, $A R$ 1940, 122. For two good graphs see Ontario, AR 1939, 174 (1900-40), and Ontario, AR 1944, 162 (1925-44).

61 In $1921 / 22$, for example, in four provinces with some $40 \%$ of Canadian teachers (excluding Quebec), 57.1\% were rural teachers: DBS, Annual Report 1922, 130-33 (our calculations). As late as 1943 a third of all teachers in Canada worked in one-room schools: The School 32, 1 (Sept. 1943): 74. For further discussion on this point see appendix, section 10 . 
62 CTF, Trends, 132. The figures given for average annual "wages and board" for farm help, male or female, province by province, in 1925 are all well below the average salaries of teachers in the corresponding provinces in 1926. Compare Labour Gazette, Jan. 1927, Supplement: Wages and Hours of Labour in Canada, 1920 to 1926, Report No. 10, Department of Labour, p. 62, with relevant tables in CTF, Trends.

63 Supplement to the Handbook of Agricultural Statistics, prepared by the Economics Division, Department of Agriculture, Ottawa, from statistics published by the DBS (Ottawa, March 1960), 29.

64 The aim of these alternative estimates was to create approximate equivalencies with urban wage- and salary-earners. A DBS study that attempted to incorporate the costs of housing, food, and fuel along with earned income gave an average equivalent farm income of $\$ 1,050$, though Leonard Marsh thought this unduly high and preferred, for 1931, a figure of $\$ 950$. In any case, unlike the CTF figures, the DBS estimate was for farm family incomes and thus a total that usually included more than one family member. Whether or not that total represented the value of one or several productive members of the farm unit, the teacher's salary was still paid out of the cash income generated by the unit. For these estimates see Marsh, Canadians In and Out of Work, 174-75.

65 Nova Scotia, AR 1929, xv; Ontario, $A R$ 1930, Table 4(A), p. 94.

66 The School XXI, 4 (Dec. 1932): 357 (Alberta); New Brunswick, AR 1919-20, xiv, and Picot, Teacher Training in New Brunswick, 67.

67 J.D. Wilson, "Lottie Bowron and Rural Women Teachers," in Women Who Taught, 206. The author is using a 52-week figure for the teacher's salary, in order to compare it to other salaries (private communication, 14 Dec. 2007); if the annual wage is divided by the average number of weeks employed reported for all British Columbia female teachers in the 1931 census (49.09), the weekly wage would be $\$ 22.00$. On this kind of calculation see our commentary in the appendix, section 13 .

68 This pattern of boarding for the week and returning home (usually close by) on weekends, or living at home or with relatives while teaching in a local rural school, was typical, for example, in Saskatchewan's Kipp school (where living patterns for most teachers are documented): see University of Alberta Archives [UAA], John C. Charyk Fonds, 90-43-83, Box 10, Records from Mrs. Dorothy Willner, Minutes and related records, Kipp School District No. 1589. See also Sager, "Women teachers in Canada," 227, 229; Nova Scotia, AR 1911, 186; Dianne Hallman, "'A Thing of the Past': Teaching in One-Room Schools in Rural Nova Scotia, 1936-1941," Historical Studies in Education 4, 1 (Spring 1992): 119; Edith Van Kleek, The Way It Was: Vignettes from My One-Room Schools, ed. Thelma Jo Dobson (Calgary: University of Calgary Press, 2007), 63, 83; June Corman, "Seeking Greener Pastures: Rural Women Teachers in Southern Saskatchewan," in A History of Education in Saskatchewan: Selected Readings, ed. Brian Noonan, Dianne Hallman, Murray Scharf (Regina: Canadian Plains Research Center, University of Regina, 2006), 190. In an analysis of two Ontario inspectorates carried out for this article, we found that many rural schoolteachers had home addresses in different townships than the ones in which they worked. It's entirely possible that they were boarding outside the school sections, but if we had the household census for verification we think it likely we would find most living with family members. For details of the analysis, see section 15 of the appendix.

69 For example, see the retrospective salary tables in Ontario, $A R$ 1926, 77, and $A R$ 1940, 122; salaries for men and women in Saskatchewan, $A R$ 1926, 49, and $A R$ 1930, 50. Ontario and Saskatchewan figures are for elementary teachers only, which helps to disentangle some of the effects of a segmented labour market. For a graphic display of the differences between salaries for men and women in the countryside, 1900 to 1938, see Ontario, AR 1939, 174. 
70 Schools and Teachers in the Province of Ontario (Toronto: 1911-1966); familiarly known as "the Blue Books." The two inspectorates were selected because each, in quite different areas of the province, contained a high proportion of rural schools. For extended commentary on this micro-study, see the appendix, section 15 . See also the related tables A3 to A6 in the appendix.

71 The proportion of first-class-certificate teachers in the one-room schools was much smaller: in $1920,11 \%$ of men and $2 \%$ of women; $1925,18 \%$ and $6 \%$ respectively; $1930,18 \%$ and $23 \%$. In 1920 such female teachers were exceptional and they earned on average the same as men; a differential in salaries had occurred by 1925 , when women earned $92 \%$ of male salaries, and continued in 1930, at $94 \%$.

72 UAA, Charyk Fonds, 90-43-83, Box 10, Kipp School District No. 1589.

73 For figures and commentary on the number of one-room schools, see the appendix, section 10.

74 Rank within the school played a major role, of course: most male teachers in the towns were principals, most women were assistants. But higher rank was often associated with better qualifications and longer experience as well.

75 See, as one example, Table A3 in the appendix for our two Ontario inspectorates; see also Carol A. Small, "An Analysis of Principals in Southwestern Ontario, 1920-1969" (University of Western Ontario, Faculty of Education, Directed Research Project, 1996).

76 See for example Richardson, Administration of Schools, 180; Family Herald, reprinted in Alberta Teachers' Alliance [later, Association] Magazine [ATA Magazine] II, 9 (Feb. 1922): 5; C.E. Mark, The Public Schools of Ottawa (Ottawa: Pattison Print, 1918), 46-47. There were exceptions: see for example "Report of People's Panel, Provincial Salary Committee," BC Teacher XII, 4 (Dec. 1932): 29; “CTF Report on Salary Schedules," BC Teacher XVIII, 4 (Dec. 1938): 157-58.

77 For more details on this point, see the appendix, section 11.

78 DBS, Annual Survey 1931, xii. For our own analysis of one of the rare data sets that allows us to separate, for their influence on male and female salaries, the factors of experience, qualifications, and rural/urban teaching, see the appendix, section 14 and related Table A7.

79 See Veronica Strong-Boag, The New Day Recalled: Lives of Girls and Women in English Canada, 1919-1939 (Toronto: Copp Clark Pitman, 1988), 51-54.

80 For progress through the grades, see for example DBS, Annual Report 1922, 14, 48; DBS [M.C. MacLean], Illiteracy and School Attendance in Canada (Ottawa, 1926), 93-94; DBS, "The School Standing Attained by Canadian Children," mimeograph, 1931, p. 1.

81 For the sources here see the appendix, section 8.

82 See for example the comments in Proceedings, OEA, 1901, 391; ibid., 1906, 264; Ontario, AR 1920, 49; New Brunswick, AR 1913-14, xl. For a broader discussion of this issue see Claudia Goldin, Understanding the Gender Gap: An Economic History of American Women (New York: Oxford University Press, 1990), 88ff., esp. the section on "Discrimination and 'Wage Discrimination'."

83 "School-Marm a Menace? Reply to Mr. Woollacott. By a Woman Teacher," Maclean's Magazine, 1 Jan. 1937, p. 33.

84 ATA Magazine 1, 5 (Nov. 1920): 28; WSJ XIV, 11 (Nov. 1919): 363.

85 Alberta, $A R$ 1920, 15.

86 Nova Scotia, AR 1932-33, xxvii-xxviii. Such sentiments had been common coinage since early in the century. For other examples see Educational Review (Feb. 1902): 185; Proceedings, OEA, 1901, 391-92; ibid., 1906, 264; ibid., 1909, 322; ibid., 1919, 199.

87 Winnipeg School Board, $A R$ 1933, 16-17. Hiring men for senior elementary classes was not new in the 1930s. See for example, for policies in Toronto, Educational Review (Feb. 
1902): 185; for Victoria, Alison Prentice et al., Canadian Women: A History (Toronto: Harcourt Brace Jovanovich, 1988), 129; London Board of Education, AR 1904, 7; AR 1905, 6; AR 1910, 6.

88 "Report of People's Panel, Provincial Salary Committee," BC Teacher XII, 4 (Dec. 1932): 17-18. The document went on to buttress the argument with a lengthy appendix from an English commission justifying the same principle: 43-45.

89 N. Burwash, "The Social Status of the Teacher," Proceedings, OEA, 1905, 75; similarly see A. McMillan, "Means of Retaining the Services of Male Teachers...," Proceedings, OEA, 1905, 208.

90 Marsh, Canadians In and Out of Work, 178.

91 Nova Scotia, AR 1932-33, xxvii; Alberta, AR 1920, 15. See also Proceedings, OEA, 1912, 125-26, and ibid., 1918, 324-25. Though we are referring here to the twentieth century, the lingering influence of nineteenth-century views on the gendered and classspecific conceptions embedded in the meaning of "profession" are explored in R.D. Gidney and W.P.J. Millar, Professional Gentlemen: The Professions in Nineteenth-Century Ontario (Toronto: University of Toronto Press, 1994).

92 See for example WSJ I, 2 (Feb. 1902): 15-16; New Brunswick, AR 1913-14, xi. This was not a new problem however; again, see for the later nineteenth century, Gidney and Millar, Professional Gentlemen, 232-47; see also Proceedings, OEA, 1905, 76-77, 208-9; ibid., 1908, 101.

93 See the table and commentary, DBS, Annual Survey 1930, xiv.

94 See Proceedings, OEA, 1906, 130-31; ibid., 1920, 487-89; Ontario, AR 1920, 49; The School 8, 1 (Sept. 1919): 36-38 (commentary from Alberta).

95 WSJ XVI, 6 (June 1921): 662-63. On the problem generally see also WSJ I, 2 (Feb. 1906): 15-16; Proceedings, OEA, 1909, 321-23; WSJXIV, 5 (May 1919): 158-59; WSJ XIV, 11 (Nov. 1919): 363-65; Nova Scotia, AR 1919-20, 159; Educational Review (June 1920): 249; ATA Magazine I, 5 (Nov. 1920): 28; Ontario, AR 1920, 49; Manitoba Teachers' Federation Bulletin, No. 28 (Dec. 1923): 495-97; New Brunswick, AR 1925, 19; Alberta, AR 1925, 12.

96 For one example zeroing in on salaries, see the editorial, BC Teacher XI, 3 (Nov. 1931): $1-2$. This complaint about low salaries generally is followed in the next paragraph by a comparison to the salaries of doctors, lawyers, and other professional men, and of businessmen. There is no reference to women's earnings either for women generally or for women teachers. For an earlier example that focuses on the need for an improved pension scheme, see "Memorial of the Ontario Educational Association to the Minister of Education," Proceedings, OEA,1912, 9. Both strike us as classic cases of cognitive dissonance: on the one hand, an occupation predominantly consisting of women, and on the other, arguments for improved salaries or pensions premised on the particular needs of men. If it had been true that men stood "for permanency in the profession" and women were mere "birds of passage," the argument might have carried at least some plausibility. But that was not the case. From early on it was well known that turnover among the men was also high: see for example the essay by Professor Walter C. Murray, "Present Special Position and Prospects of Teaching as a Profession," in New Brunswick, AR 1899, Appendix G, 160-61. Moreover, in terms of raw numbers (as against percentages) there were always as many or more career teachers among women as men. Yet wherever men were to be found as the spokesmen for professional interests, the issue was men's salaries and, concomitantly, their status concerns and not those of even the career women teachers who were their peers. Though writing about only one province and with a more limited time frame, Irene Poelzer, in a fine essay on the subject, anticipates several of the arguments we offer here, in Saskatchewan Women Teachers, 1905-20: Their Contributions (Saskatoon: Lindenblatt and Hamonic, 1990), 44-48 and 56-60. For challenges to gender-based salary inequities, see for example 
Agnes Purvis, "Men or Women Teachers," Proceedings, OEA, 1906, 264-71; Women's Federation President's Address, ibid., 1919, 250-54; Address by E.A. Marty to FWTAO, ibid., 1920, 25; Address by Miss Petit, FWTAO, ibid., 1921, 34-35; Educational Review (Nov. 1927): 51.

97 Royal Commission on Dominion-Provincial Relations [RCDPR], Report, Book I, 205-6.

98 Ontario, Report of the Committee of Enquiry into the Costs of Education in the Province of Ontario, 1938, 22.

99 John W. Chalmers, Schools of the Foothills Province: The Story of Public Education in -Alberta (Toronto: University of Toronto Press, 1967), 84-85; The School 19, 10 (June 1931): 992. For Manitoba see The School 24, 2 (Oct. 1935): 165. By the mid-thirties the scarcity of jobs and department of education policies restricting the numbers of entrants and/or raising entry standards reduced enrolments in nearly every province.

100 The School 23, 4 (Dec. 1934): 349. Similarly see The Manitoba Teacher 12, 9 (Nov. 1931): 1.

101 Cited in Strong-Boag, New Day Recalled, 45.

102 The School 19, 8 (April 1931): 796.

103 The 1931 Canada census reported that only about 3\% of women teachers were married. It may be that the census was taken too early to reflect the influx. But other sources took note of large numbers: in 1931 in Saskatchewan, for example, "fully one thousand" married women teachers; The School 19, 8 (April 1931): 796. Similarly see The Manitoba Teacher 12, 1 (Jan. 1931): 2; Saskatchewan, AR 1934, 38; ATA Magazine XI, 9 (May 1931): 3; Chalmers, Foothills, 84. For the phenomenon in parts of Nova Scotia see Nova Scotia, $A R$ 1933, 41. By 1941, in any case, the census recorded that $10.5 \%$ of women teachers were married; see DBS, Survey of Elementary and Secondary Education in Canada, 1944-46, 28-29.

104 The School 21, 9 (May 1933): 812. For sources and commentary here, see the appendix, section 17.

105 For these pressures in rural areas, see for example RCDPR, The Case for Alberta, 1938, 269; RCDPR, Report of Hearings, Manitoba, Vol. 1: 331-32.

106 DBS, Annual Survey 1936, viii.

107 The Manitoba Teacher 15, 1 (March 1934): 23.

108 Calculated from inspectorate records in Schools and Teachers... Ontario, 1930 and 1935.

109 RCDPR, Report, Book II, 51, and Report of Hearings, Saskatchewan, Vol. III, p. 1898, President, Saskatchewan Teachers' Alliance.

110 UAA, Charyk Fonds, Box 10, Minutes and related records, Kipp School District No. 1589. The teachers were usually single women but they included one young man in 1929 and in 1934 a married woman.

111 RCDPR, Submission by the Government of Nova Scotia, Feb. 1938, 132. Similarly see Nova Scotia, AR 1934, 63.

112 RCDPR, The Case for Alberta, 270.

113 Saskatchewan, AR 1935, 33; The School 27, 7 (March 1939): 624.

114 Saskatchewan, Report, Committee on School Administration, 1939 (Martin Report), 14. For many accounts of similar financial tribulations, see Elizabeth McLachlan, With Unshakeable Persistence: Rural Teachers of the Depression Era (Edmonton: NeWest Press, 1999).

115 Canadians now take it for granted that schools are funded out of the pooled resources of large geographical areas and equalized across poor and rich assessment bases. But before the 1940 s, local school districts, with a relative handful of ratepayers, many of them almost entirely dependent on a single economic staple, paid the lion's share of total school costs. In 1935 for example, government grants to school boards covered 20\% or less in six provinces. In Ontario, it was as little as 11.7\%, in Alberta and Manitoba around 15\%, in Nova Scotia and New Brunswick 17\%, in Saskatchewan 20\%. The 
only exceptions were British Columbia at 28\% and Prince Edward Island at 54\%. Our calculations, DBS, Survey of Elementary and Secondary Education in Canada, 1942-44, $73 \mathrm{ff}$.

116 RCDPR, Report, Book I, 146.

117 Ibid., 187.

118 Nova Scotia, AR 1933, 66.

119 RCDPR, Report, Book I, 197.

120 Gerald Friesen, The Canadian Prairies: A History (Toronto: University of Toronto Press, 1984), 388.

121 RCDPR, Report, Book I, 148.

122 Marsh, Canadians In and Out of Work, 298, Table 46.

123 For a graphic representation of wage and price indices, 1926-40, see Historical Atlas of Canada, ed. Donald Kerr and Deryck W. Holdsworth, Vol. III: Addressing the Twentieth Century, 1891-1961 (Toronto: University of Toronto Press, 1990), Plate 41. For a sample of Canadian cities see Emery and Levitt, "Cost of living, real wages and real incomes in thirteen Canadian cities," esp. Tables $2 \mathrm{a}$ and $2 \mathrm{~b}$.

124 See William J. McCordic, Financing Education in Canada (Ottawa: Canadian Conference on Education, 1960), 22, Table 12.

125 CTF, Trends, 23-28, and 133, Table 5 (in constant dollars). See esp. the graphic, 27. The CTF figures differ from those in McCordic, Financing Education, because constant dollars are calculated from different bases in each study, but both sets of figures agree on the trend of salaries from 1929 to 1938.

126 See CTF, Trends, relevant tables, 51-68.

127 CTF, Trends, 48-49, Tables 1.1 and 1.3; 132, Table 4.

128 Hallman, "A Thing of the Past," 119.

129 See for example The Manitoba Teacher 16 [sic: 15], 2 (May-June 1934): opposite p. 1; ibid., 16, 1 (March 1935): 27, 29, and back cover; The School 19, 9 (May 1931): 913, and 24, 8 (April 1936): 717, 719; Educational Review (Dec. 1930): 85; BC Teacher X, 5 (Jan. 1931): opposite p. 41 (an ad for Thomas Cook summer tours to Europe, costing \$698, and the Orient, for \$1,055); ibid., XII, 6 (Feb. 1933): 31; ATA Magazine XV, 8 (April 1935): 16-17, and inside back cover; ibid., XVI, 3 (Nov. 1935): 13. For an illuminating analysis of the non-financial rewards that young women teachers reaped from their work, in the 1930s as well as in other years, see Rebecca Priegert Coulter, "'Girls Just Want To Have Fun': Women Teachers and the Pleasures of the Profession," in History is Hers: Women Educators in Twentieth-Century Ontario, ed. Rebecca Priegert Coulter and Helen Harper (Calgary: Detselig Enterprises, 2005), 211-29.

130 Our calculations from F.H. Leacy, ed., Historical Statistics of Canada, $2^{\text {nd }}$ ed. (Toronto: Statistics Canada, 1983), Series W150-91. This change in the proportion of men versus women teachers in the 1930s was an unusual occupational pattern. See for example Eric W. Sager, "Women in the Industrial Labour Force: Evidence for British Columbia, 1921-53," BC Studies, No. 149 (Spring 2006): 46-49.

131 For qualifications, our calculations from M.C. Urquhart and K.A.H. Buckley, eds., Historical Statistics of Canada (Toronto: Macmillan Co. of Canada, 1965), 594-95; for experience, our calculations from Ontario, $A R$ 1930, 142, and Ontario, AR 1938, 114; DBS, Annual Survey 1930, 62-64, Annual Survey 1936, 54-55, Elementary and Secondary Education 1936-38, 60-67, and Elementary and Secondary Education 1938-40, 70-77.

132 See Noah M. Meltz and David Stager, The Occupational Structure of Earnings in Canada, 1931-1975 (Ottawa: Minister of Supply and Services, Canada, 1979), 147, 149. The authors are comparing the 1931 and 1941 census, which might suggest a decadal decline, but both the CTF and McCordic studies made it clear that decline was occurring only from the later 1930s. 
133 The bulletin is reproduced in BC Teacher XIX, 6 (Feb. 1940). The quotation is on p. 294.

134 The 1957 CTF study, for example, treats the issue of salaries as crucial for both men and women, and indeed asserts that the immediate problem at hand is "how to attract more of the capable men and women into the profession" and retain both: CTF, Trends, 3. Though beyond our scope here, this shift in sensibility deserves attention and explanation.

135 The Winnipeg School Board ARs routinely take note of obituaries and retiring teachers, providing clear evidence of substantial numbers of teachers serving twenty to thirty years or more. See also London Board of Education, $A R$ 1922, 7-8; AR 1930, 37; AR 1939,28 . Many of the urban school teachers in our two Ontario inspectorates had similar long careers B we traced eight (out of seventeen) from 1920 who were still working at the same schools in 1938.

136 See CTF, Trends, esp. chap. II. 